IFN Working Paper No. 894, 2012

\title{
Is Welfare Dependency Inherited? Estimating the Causal Welfare Transmission Effects Using Swedish Sibling Data
}

Karin Edmark and Kajsa Hanspers 


\title{
Is welfare dependency inherited? Estimating the causal welfare transmission effects using Swedish sibling data
}

\author{
by \\ Karin Edmark $^{\mathrm{a}}$ and Kajsa Hanspers ${ }^{\mathrm{b}}$
}

January 2, 2012

\begin{abstract}
This study tests whether individuals who grow up with parents on welfare benefits are themselves more (or less) likely to be welfare recipients as young adults, compared to individuals who grow up in non-welfare households. We use the sibling difference method to identify causal effects separately from the effects of correlated factors. While a descriptive analysis reveals a fairly high positive intergenerational correlation, especially in the late teens and conditional on a large set of household level factors, the sibling analysis provides no support for a causal effect of parents' welfare benefit receipt on children's future welfare use.
\end{abstract}

Keywords: Welfare benefits, intergenerational mobility, sibling approach.

JEL-codes: I3 J1

\footnotetext{
* Constructive and useful comments from Eva Mörk, Markus Jäntti, Per-Anders Edin, Erik Grönqvist and seminar participants at Uppsala University, Umeå University, IFAU, the 2008 IIPF Annual Congress in Maastricht, and the $8^{\text {th }}$ Journées Louis-André Gérard-Varet in Marseille. Research grants from the Swedish Council for Working Life and Social Research (FAS), and from the Jan Wallander and Tom Hedelius Foundation are gratefully acknowledged.

${ }^{a}$ The Research Institute of Industrial Economics, IFAU, UCFS, UCLS. Email: Karin.edmark@ifn.se

b Department of Economics, Uppsala University. Email: kajsa.hanspers@nek.uu.se
} 


\section{Table of contents}

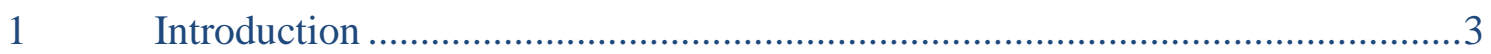

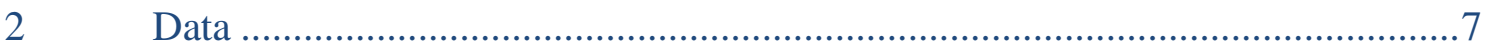

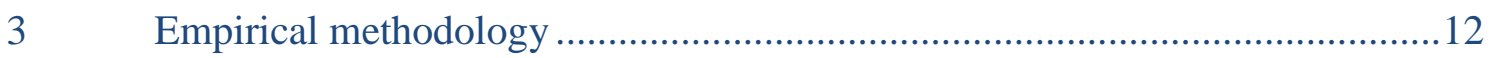

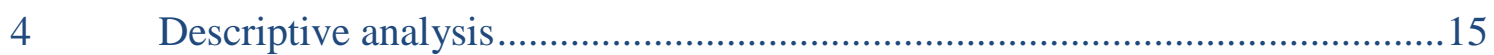

5 Estimating the causal effects using a sibling comparison approach .................19

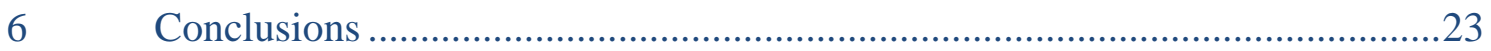

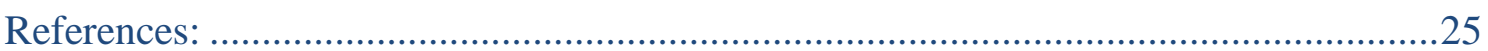




\section{Introduction}

Welfare benefit policy is an area that has received considerable political interest in many countries during the last decades. Starting with the US welfare reform of 1996, several countries have sought to reform their welfare benefit systems to decrease caseloads and increase employment. One motivation for these policies, in particular in the US, is the fear that having a large population on welfare may produce "welfare cultures"; i.e., a situation in which individuals are trapped in poverty and the use of welfare spreads through social interactions. Such interactions may occur between individuals in various social networks, for example between parents and children.

In this paper we focus on the long term effects of welfare use, and test whether the use of welfare benefits is transmitted from parents to their children. This is an important topic as it does not only reveal something about the mechanisms of welfare use, but it may also shed light on the potential long term effects of policies aimed at reducing welfare use. More precisely, this paper estimates the direct causal effects of growing up in a household that receives welfare benefits, using a sibling difference comparison on Swedish households during the 1990s.

There are several ways in which parental welfare benefit receipt could affect the children's welfare use as adults: i) children of welfare recipients may develop less of a natural connection to work life and have less access to work-related networks, which may make them more likely to receive welfare as adults; ii) children of welfare recipients may learn how the welfare benefit system works, and how life on welfare is, which may make them either more or less likely to use welfare; and iii) children of welfare recipients may experience welfare receipt as more or less stigmatizing. The effects we consider are hence related to viewing the parents as role models, to attitudes to welfare benefits, and to access to employment-related networks through the parents.

The challenge is to separate these effects of parental welfare use from other factors that are correlated with the welfare use of both parents and children. There are two types of such factors: i) the welfare receipt of parents may be correlated with other household level characteristics, which affect future welfare benefit receipt of children through the home environment; and ii) parents and children may be similar in personal characteristics that affect their likelihood of receiving welfare benefits, such as attitudes to or skills for work. Although there is a fairly large number of studies on 
intergenerational welfare transmission, especially studies based on US data, there is no clear evidence of whether the commonly observed positive intergenerational correlation in welfare benefit receipt reflects a causal effect of parental welfare benefits, or whether this correlation is the result of other factors. ${ }^{1}$

Only a few of the previous studies have attempted to separately identify the causal effects. Gottschalk (1996) attempts to capture unobserved heterogeneity by adding parental welfare benefit status measured when the child is an adult to the regression model. This approach will capture the effect of any similarities in the propensity to become a welfare benefit recipient, to the extent that they stay fixed over time and enter the model linearly. It does not, however, solve the problem of how to control for other factors - related to the home environment etc. - which are correlated with parental welfare benefits during childhood but are not fully captured by the parents' current welfare receipt.

Another approach is to instrument for parental welfare benefit receipt as the child grows up (see e.g., Pepper (2000), Siedler (2004), Maloney et al. (2003)). The idea here is to use only the variation in parental welfare benefit receipt that is exogenous - i.e., uncorrelated with other factors that affect children's future welfare benefit receipt. The problem is to find instruments that have sufficiently strong effect on parents' welfare benefit receipt as the child grows up but that have no direct effects on the child's future welfare benefit receipt. Some of the instruments that were used in the previous studies are questionable from a methodological point of view. For example, Maloney et al. (2003) use parent's educational and civil status as instruments, in spite of the fact that these may well have a direct effect on children's future welfare benefit status. The more convincing studies (see e.g., Pepper (2000)) use the local unemployment rate as instrument for parental welfare use.

To the best of our knowledge, the only previous study on intergenerational welfare benefit transmission in Sweden is Stenberg (2000), in which the intergenerational correlations for a sample of approximately 12,000 individuals born in 1952 are estimated. The study includes an extensive set of control variables, and the results suggest a positive correlation in the welfare benefit receipt of children and parents in households where other social problems are also present, such as behavioral problems in

\footnotetext{
${ }^{1}$ See e.g. Antel (1992), Gottschalk (1990) and (1996), Pepper (2000), Siedler (2004), Maloney et al. (2003), and Stenberg (2000).
} 
school or having a father with a criminal record, but not in households without such problems.

The sibling-based approach that is used in this paper relies on using a difference-indifference (DID) estimator to control for the influence of omitted variables that are correlated with the welfare benefit receipt of both parents and children. The findings in Stenberg (2000) highlight the fact that family level factors, which are often not detectable to the researcher and are likely to be correlated with welfare benefit receipt, may be important to control for to isolate the causal effects of welfare. This makes the sibling difference analysis particularly appealing, because it in effect controls for all observed and unobserved family level characteristics that stay fixed over time.

We have access to detailed register data on all Swedish individuals aged 16-64, including information on welfare benefit payments and family connections, and several socio-economic and demographic background variables. Using these rich data, we are able to construct a data set that meets our requirements for the sibling difference analysis. Specifically, we extract a sample of two types of families with (at least) two children: i) in which the parents received no welfare benefits until the older sibling was 24 , but started to receive welfare benefits after that; and ii) in which the parents never received welfare benefits until both siblings had turned 24. This sample is used to estimate the effect of parental welfare benefit receipt on the likelihood that the child receives welfare at the age of $24 .^{2}$

The fact that we use a DID-specification, means that we rely on variation between younger and older siblings, and between types of families, to identify the effect. First, we take the difference in welfare benefit receipt at age 24 between the older and younger siblings, in families in which the younger but not the older sibling was exposed to parental welfare receipt before age 24 . That is, we use only families in which the parents started to receive welfare benefits after the older sibling had turned 25 . Second, we subtract the corresponding between-sibling difference among the families where the parents never received welfare. The appeal of this specification is that the first difference controls for family level factors to the extent that they stay fixed over time and affect older and younger siblings in a similar manner, while the second difference controls for factors that are specific to the time period during which we measure the

\footnotetext{
${ }^{2}$ As will be discussed further in section 4.2 , we hence use a specific sample of individuals for the analysis, and this affects the generalizability of the results.
} 
outcome variable, as long as these factors have a similar effect on children from the two types of families.

To this DID-specification, we add a set of time-varying covariates, and we add time trends interacted with a set of predetermined factors that are correlated with welfare benefit propensity. This helps control for household level and other factors that are not captured by the DID-specification. The estimation details will be further discussed in section 3 .

The sibling difference method has been used in several areas, such as returns to schooling (Ashenfelter \& Zimmerman (1997)) and intergenerational effects in unemployment (Ekhaugen (2005)). The study that is most closely related to this, Levine and Zimmerman (2005), applies the sibling difference method to test the effects of maternal welfare benefit receipt on children's developmental outcomes, such as educational attainment. Their results show no evidence of a causal link between maternal welfare receipt and children's outcomes.

Our study is also related to the literature on intergenerational income mobility. The aggregate evidence from these studies suggests a positive correlation between parents' and children's income, although the estimated magnitudes of this correlation vary. ${ }^{3}$ Björklund \& Jäntti (1997), for example, show that the income mobility seems to be larger in Sweden than in the US. Other studies investigate the intergenerational transmission of poverty, such as Duncan et al. (1998) and Airio et al. (2005), and find that the risk of poverty in adulthood is larger for individuals growing up in poor families.

The results of our analysis confirms a positive correlation between children's and parents' welfare benefit receipt in the data, even after we control for a large number of observable household level characteristics. However, our DID-based sibling analysis, which conditions on unobserved heterogeneity, yields no support for a causal effect of parental welfare benefit receipt on children's future welfare benefit use.

The organization of the remaining sections is as follows: section 2 describes the data used, section 3 presents and discusses the empirical model, and section 4 contains a descriptive analysis. Section 5 presents and discusses the results, and section 6 concludes.

\footnotetext{
${ }^{3}$ See e.g. Solon (1992), Corak \& Heisz (1999), Chadwick \& Solon (2002.
} 


\section{Data}

We are fortunate to have access to register data on incomes and demographic variables for all Swedes aged 16-64 from 1990-2007. The information on welfare benefits is in the form of the total yearly amount (in SEK currency) of welfare benefits received by the household. The data also contains a number of socio-economic factors, such as disposable income, other types of benefits (sickness benefits, sickness pension benefits and benefits for disabled) and information on family characteristics and educational attainment. Importantly, we are able to link parents and children (biological and adopted), and from age 16, we observe whether the children and parents live in the same household or whether the child has moved out. ${ }^{4}$

We use these data to construct a data set consisting of all sibling pairs in which the siblings are born in 1973 and 1981, in 1974 and 1982, or in 1975 and 1983. ${ }^{5}$ Therefore, there is an 8-year difference between the sibling pairs in our data. This is admittedly a long period, but it is necessary as we want to be able to measure the outcome variable welfare benefit receipt as a young adult - of the older sibling before the start of a potential parental welfare benefit spell.

We measure the children's exposure to parental welfare when they are $17-19 .^{6}$ This means that we omit sibling pairs in which the parents received welfare when the older sibling was 17-19. This provides approximately 5000 families to use for the estimations. The outcome variable, children's welfare use, is measured as the children are 24 years old.

Figure 1 shows the aggregate unemployment and welfare benefit rates in 1980-2006 (with welfare benefits starting from 1983 on). ${ }^{7}$ Before 1993-94, the welfare benefit levels were relatively constant at approximately 6 percent, but between 1992 and 1994, they rose to more than 8 percent and remained high until the late 1990s. The shaded areas in the figure show when the older (dark gray) and the younger (light gray) siblings are 17-19 years old, which is the age when the younger siblings are potentially exposed to parental welfare benefits. The circles denote the years in which the outcome is

\footnotetext{
${ }^{4}$ We include only children who live with their mother at age 17 and who do not live with their parents at age 24 .

${ }^{5}$ Twins and other siblings that are born during the same year are excluded from the sample.

${ }^{6}$ The fact that the first year of the data set is 1990 means that the first year we observe the family characteristics is when the children in cohorts 1981-83 are 7-9 years old, and when the children in cohorts 1973-75 are 15-17. How this might affect the results is discussed in section 3 .

${ }^{7}$ The aggregate welfare benefit rate in Figure 1 includes economic support to recent immigrants. Recent immigrants are however excluded from the regression analysis of the paper.
} 
measured for the three cohorts of older (dark gray) and younger (light gray) siblings. It is worth pointing out that the outcome of the older sibling is always measured one year before the start of the younger sibling's exposure to parental welfare receipt to ensure that the outcome of the older control cohorts is not directly affected by the welfare benefit receipt of their parents. 
Figure 1 Unemployment and welfare benefit rates ${ }^{8}$

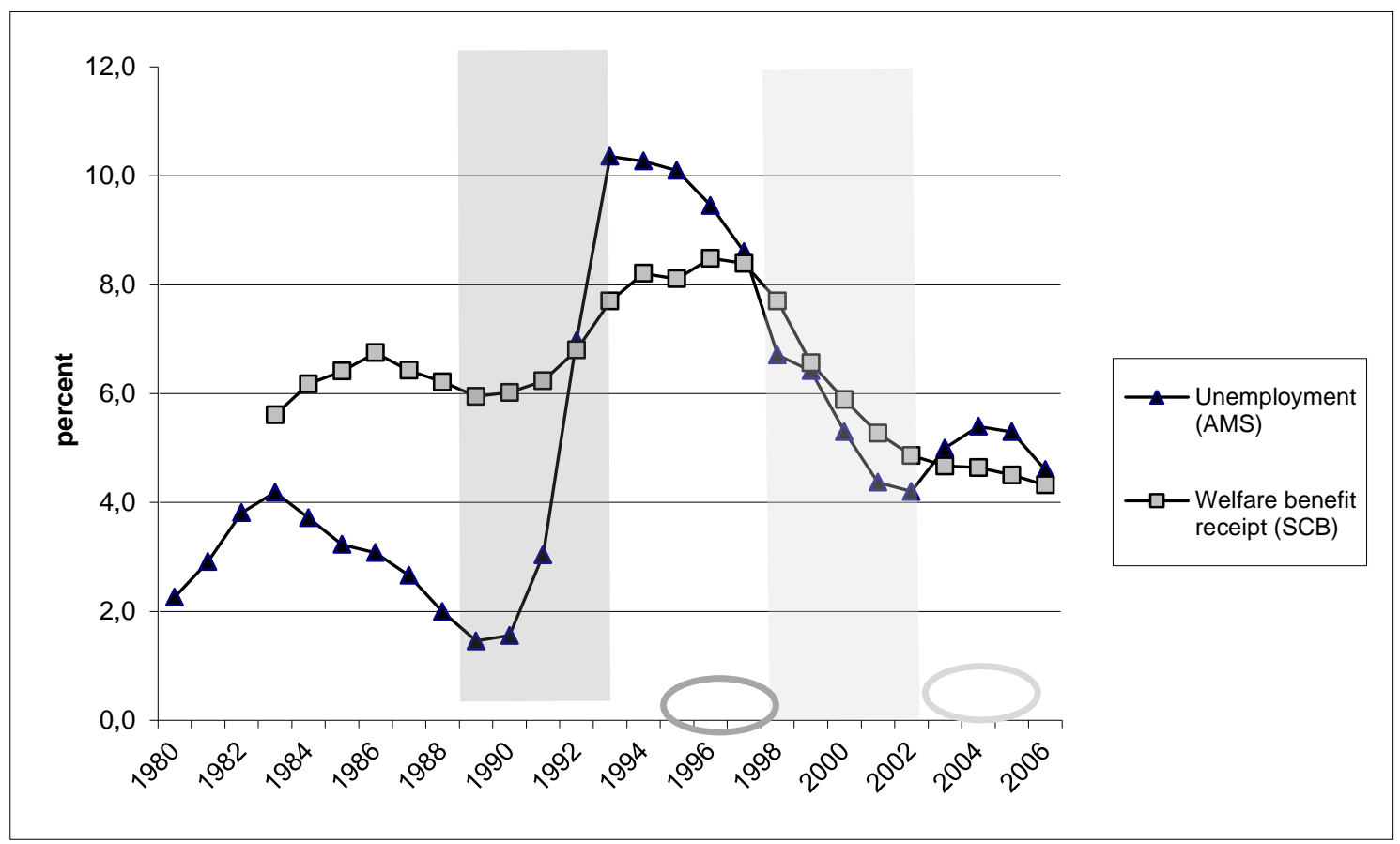

Source: The National Labor Market Board (AMS) and Statistics Sweden (SCB).

The variables that are included in the regression analysis are summarized in Table 1. All monetary variables have been deflated to year 2005 's price level. Table 1 contains the average values of the main variables by welfare status of the families. We can see that both young and old siblings from families that have received welfare are more likely to receive welfare as adults. Welfare benefit receipt is also more common if the parents in these families are born outside of Sweden, have lower education, are not employed and have received sickness benefits. Finally, we observe that old siblings are generally more likely to receive welfare benefits than young siblings, which is a fact that probably mirrors the tougher labor market situation facing the adult older siblings (see Figure 1).

\footnotetext{
${ }^{8}$ Welfare benefit rates refers to the share of individuals all ages that live in households that received welfare benefits at some point during the year.
} 
Table 1 Family characteristics of the sibling sample, by welfare status

\begin{tabular}{|c|c|c|c|c|}
\hline & \multicolumn{2}{|c|}{ Families with welfare } & \multicolumn{2}{|c|}{ Families without welfare } \\
\hline & $\begin{array}{l}\text { Younger } \\
\text { sibling }\end{array}$ & $\begin{array}{l}\text { Older } \\
\text { sibling }\end{array}$ & $\begin{array}{l}\text { Younger } \\
\text { sibling }\end{array}$ & $\begin{array}{l}\text { Older } \\
\text { Sibling } \\
\end{array}$ \\
\hline \multicolumn{5}{|l|}{ Indicators of welfare benefit status: } \\
\hline Child welfare at 24 & 0.140 & 0.246 & 0.028 & 0.061 \\
\hline Parental welfare during ages $17-19$ & 0.974 & 0.000 & 0.000 & 0.000 \\
\hline Parental welfare share of years $17-19$ & 0.466 & 0.000 & 0.000 & 0.000 \\
\hline Parental welfare/ year 17-19 & 6,885 & 0.000 & 0.000 & 0.000 \\
\hline \multicolumn{5}{|l|}{ Household characteristics during childhood: } \\
\hline Divorce during ages $17-19$ & 0.057 & 0.079 & 0.031 & 0.028 \\
\hline Single mother share of years $17-19$ & 0.364 & 0.171 & 0.131 & 0.068 \\
\hline $\begin{array}{l}\text { Disposable family income total 17-19 (1000 } \\
\text { SEK) }\end{array}$ & 630 & 975 & 746 & 1065 \\
\hline Sickness benefits mother share of years $17-19$ & 0.264 & 0.457 & 0.195 & 0.337 \\
\hline Sickness benefits father share of years $17-19$ & 0.136 & 0.407 & 0.121 & 0.282 \\
\hline Sickness pension mother share of years $17-19$ & 0.174 & 0.080 & 0.070 & 0.021 \\
\hline Sickness pension father share of years $17-19$ & 0.114 & 0.058 & 0.046 & 0.014 \\
\hline Disability pension mother share of years $17-19$ & 0.016 & 0.005 & 0.005 & 0.003 \\
\hline Disability pension father share of years $17-19$ & 0.003 & 0.000 & 0.004 & 0.003 \\
\hline Mother not employed share of years 17-19 & 0.316 & 0.211 & 0.105 & 0.102 \\
\hline Father not employed share of years $17-19$ & 0.242 & 0.134 & 0.082 & 0.068 \\
\hline \multicolumn{5}{|l|}{ Parental characteristics: } \\
\hline Age of mother at child's birth & 31.280 & 23.314 & 32.048 & 24.152 \\
\hline Mother's age at immigration ( $=0$ if native) & 2.238 & 2.377 & 0.942 & 0.670 \\
\hline Father's age at immigration ( $=0$ if native) & 3.347 & 2.356 & 1.223 & 0.786 \\
\hline Mother born in Sweden & 0.902 & 0.885 & 0.959 & 0.960 \\
\hline Mother born in Nordic country & 0.041 & 0.042 & 0.029 & 0.028 \\
\hline Mother born in Western country & 0.005 & 0.005 & 0.004 & 0.004 \\
\hline Mother born in East Europe & 0.010 & 0.010 & 0.003 & 0.003 \\
\hline Mother born outside Europe/Western country & 0.041 & 0.058 & 0.005 & 0.005 \\
\hline Father born in Sweden & 0.881 & 0.880 & 0.957 & 0.956 \\
\hline Father born in Nordic country & 0.052 & 0.031 & 0.020 & 0.021 \\
\hline Father born in Western country & 0.010 & 0.021 & 0.008 & 0.010 \\
\hline Father born in East Europe & 0.010 & 0.005 & 0.007 & 0.007 \\
\hline Father born outside Europe/Western country & 0.047 & 0.063 & 0.007 & 0.007 \\
\hline $\begin{array}{l}\text { Mother finished primary school at age } 19 \text { of the } \\
\text { child }\end{array}$ & 0.264 & 0.340 & 0.165 & 0.189 \\
\hline Mother finished high school at age 19 of the child & 0.523 & 0.461 & 0.498 & 0.496 \\
\hline Mother finished college at age 19 of the child & 0.212 & 0.199 & 0.336 & 0.316 \\
\hline Father finished primary school at age 19 of the & 0.321 & 0.366 & 0.263 & 0.285 \\
\hline
\end{tabular}




\begin{tabular}{lcccc}
\hline & \multicolumn{2}{c}{ Families with welfare } & \multicolumn{2}{c}{ Families without welfare } \\
\hline & $\begin{array}{c}\text { Younger } \\
\text { sibling }\end{array}$ & $\begin{array}{c}\text { Older } \\
\text { sibling }\end{array}$ & $\begin{array}{c}\text { Younger } \\
\text { sibling }\end{array}$ & $\begin{array}{c}\text { Older } \\
\text { Sibling }\end{array}$ \\
\hline child & & & & \\
Father finished high school at age 19 of the child & 0.466 & 0.429 & 0.429 & 0.419 \\
Father finished college at age 19 of the child & 0.212 & 0.204 & 0.308 & 0.296 \\
Children in the household at age 19 of the child & 0.409 & 2.199 & 0.259 & 1.836 \\
Local characteristics at age 24 of the child: & & & & \\
Local unemployment & 3.893 & 6.057 & 3.715 & 5.641 \\
Observations & 193 & 191 & 4588 & 4825 \\
\hline
\end{tabular}

As shown in the Table 1, we use several measures of parental benefit receipt. First, a dummy variable, Parental Welfare 17-19, indicates whether the parent received welfare benefit at any time as the child grew up, defined as when the child is 17-19 years old. Second, we generate variables for the share of years during ages 17-19 that the parents received welfare benefits, Parental welfare share of years 17-19, as well as for the average yearly amount of benefits paid out during this period, Parental welfare/year. To measure the welfare use of the children as young adults, we generate a dummy variable, which equals one if the child received any welfare benefits at the age of 24 .

Table 1 also shows the large number of family level characteristics measured as the child grows up (age 17-19), which will be used in the analysis. These include variables measuring the following: whether the parents got divorced during this period, Divorce 17-19; the share of years the household was a single parent household, Single mother share yrs 17-19; the number of children ages $0-17$ in the household measured as the child is 19, Nr children 0-17 at age 19; the age of the mother as the child is born, Age of mother at child's birth; a set of dummy variables measuring the parents' education levels as the child is 19; and their region of birth. Furthermore, we include measures of the share of years, measured as the child is 17-19, that the parents received sickness benefits and disability pension, respectively, and we include measures of the share of years the parents were outside employment. Family disposable income will be included in some of the regression specifications ${ }^{9}$, and we include the unemployment rate in the municipality where the child resides at age 24 .

\footnotetext{
${ }^{9}$ It can be discussed whether the income level should be controlled for, since being low income household is an inherent part of being a welfare recipient. This will be discussed further in section 4 .
} 


\section{Empirical methodology}

This section describes the details of the empirical specification. As a starting point, we define the baseline regression equation as follows: ${ }^{10}$

$S_{i m}^{C}=\alpha+\beta S_{i}^{P}+\phi Z_{i}^{P}+\lambda U_{m}+\varepsilon_{i m}$

where $S_{i m}^{C}$ measures the welfare benefit use of child $i$, living municipality $m$, as a young adult. The explanatory variable of interest is $S_{i}^{P}$, which measures the welfare benefits of the parents as the child grows up. ${ }^{11} Z_{i}^{P}$ denotes a set of other parental and family variables as the child grows up; $U_{m}$ is the unemployment rate in the municipality of residence of the adult child; and $\varepsilon_{i m}$ is a random error term.

While correlations resulting from a regression model, such as equation (1), are certainly interesting in themselves, they may not, as previously discussed, reveal the causality of the effects. Is an observed correlation between parental welfare participation and the child's outcome really the effect of the welfare participation, or is it due to some omitted family characteristic, or to similarities between parents and children, which are also correlated with welfare use?

To control for unobserved family heterogeneity, we turn to the sibling difference analysis. Because this method uses within-family variation, i.e., variation in exposure to parental welfare benefit receipt between siblings in the same family, it will in effect control for the influence of all family level heterogeneity that is fixed over time. The household level covariates will hence now only enter in the regression to the extent that they change over time. Estimating the sibling difference equation amounts to adding a family fixed effect, $\alpha_{j}$, as well as a time cohort effect ${ }^{12}, T_{i}$, to equation (1):

$$
S_{i j m}^{C}=\alpha_{j}+\beta S_{i j}^{P}+\phi Z_{i j}^{P}+\gamma T_{i}+\lambda U_{m}+\varepsilon_{i j m}
$$

Under the assumption that all unobserved family heterogeneity that is correlated with parental welfare benefit receipt and the outcome variable is captured by the inclusion of

\footnotetext{
${ }^{10}$ We use a linear probability model in this paper but all regressions have also been estimated by a probit model, which gives a similar result. The results from these regressions are available upon request.

${ }_{11}^{11}$ Only two parent and single mother households are included in the analysis.

12 This captures differences in the outcomes of the young and the old siblings that are due to the fact that the outcomes for the old and young siblings are measured at different points in time, with different labour market opportunities etc.
} 
the family fixed effects, the $\beta$-coefficient in equation (2) will capture the causal effects of being exposed to parental welfare benefit receipt. Therefore, the crucial assumption for our method to work is that there are no trends in unobservable factors, which affect the children's future welfare benefit receipt and differ systematically between families with and without welfare benefits. To make this assumption more plausible, we allow for the time effect, $T_{i}$, to differ with respect to a set of predetermined household level factors that are likely to be correlated with the welfare benefit propensity of parents. ${ }^{13}$ In this manner, we control for heterogeneous time trends between groups that are likely to differ in terms of the risk of receiving welfare benefits. In addition, we allow for the effect of local unemployment measured when the child is 24 , to differ between children from the two family types; one type in which the parents do not receive welfare benefits when any of the siblings are 17-19 years, and the other in which the parents receive welfare benefits as the younger, but not the older, child is 17-19. The resulting estimating equation is:

$$
S_{i j m}^{C}=\alpha_{j}+\beta S_{i j}^{P}+\phi Z_{i j}^{P}+\gamma T_{i}+\varphi\left(T_{i} \cdot W_{j}\right)+\lambda U_{m}+\eta\left(U_{m} \cdot B_{j}\right)+\varepsilon_{i j m}
$$

where $W_{j}$ is a set of predetermined household levels characteristics that tend to be correlated with welfare benefit receipt ${ }^{14}$, and $B_{j}$ equals one if the parents receive welfare benefits as the younger sibling is a 17-19 years old, and is zero otherwise.

Before we turn to the estimation of the regression equations, it is illuminating to discuss in more detail the sources of bias that could potentially affect the result. For this purpose, we first note that the $\beta$-coefficient in equation (2) can be rewritten as the expected difference in the differences in adult welfare use between young siblings $S_{y}^{C}$ and old siblings $S_{o}^{C}$, in families that differ in whether the parents received welfare benefits as the younger sibling was a teenager or not, $S_{y}^{P}=1$ or $S_{y}^{P}=0$. This expression is shown in equation (4), where for simplicity, we have omitted all other covariates:

\footnotetext{
${ }^{13}$ These are the following: Mother born in Nordic country, mother born in Western country, mother born in East European country, mother born in other country, father born in Nordic country, father born in Western country, father born in East European country, father born in other country, indicators for whether the father or mother were unemployed at any time during 1985-1990, indicators for the education level of the father and mother (primary school, high school and college) and an indicator for the mother being single any time during 1985-1990.

${ }^{14}$ Note that $W_{j}$ is a subset of the variables in $Z_{i j}$, for which we have access to predetermined information either in the form of information from previous years (1985-90), or in the form of variables that are constant over time, such as country of birth.
} 
$\hat{\beta}=E\left(\left(S_{y}^{C}-S_{o}^{C} \mid S_{y}^{P}=1\right)-\left(S_{y}^{C}-S_{o}^{C} \mid S_{y}^{P}=0\right)\right)$

Equation (4) is useful to have in mind as we discuss the different types of bias that may affect the results.

First, the fact that the data start in 1990 means that we lack information on the early childhood of the siblings - for the older siblings for the period up until they were 14-16 years old, and for the younger siblings until they were 6-8 years old. However, we do have information on a set of economic and demographic variables that are correlated with welfare benefit receipt for 1985-89, and we use these variables to predict welfare benefit receipt for these years. ${ }^{15}$ According to our predictions, none of the households in our sibling-sample received welfare benefits during 1985-89, which is reassuring.

We still, however, lack information until 1984, when the older siblings were 9-11 years old. How might this affect the results? To the extent that the children from the different types of families in our sample, in which parents either received or did not receive welfare benefits as the younger sibling was 17-19 years old, were equally exposed to previous parental welfare spells, the $\beta$-coefficient in equation (4) remains unbiased. However, if previous welfare spells differ systematically across families, this might affect the results. Perhaps the most likely case to consider is one in which parental welfare participation during the unobserved period was more common in families in which the parents also received welfare benefits as the younger sibling was a teenager, i.e., where $S_{y}^{P}=1$. This would give rise to a bias towards zero because now not only the young sibling, but also the older sibling, would to some extent have experienced, and been affected by, parental welfare receipt as a child. The fact that we do not observe the early childhood of the older siblings is therefore likely to understate the effect of parental welfare use on child welfare use.

Another scenario that could give rise to bias towards zero is the potential existence of a latent variable, which affects the welfare benefit receipt of both parents and children, but where the timing is such that it first affects welfare receipt of the older siblings, and then affects the welfare receipt of the parents. In such a situation, the welfare benefit of

\footnotetext{
${ }^{15}$ Specifically, we use the following variables to predict the probability to use welfare benefits during the year: employment status, work-related annual incomes, local unemployment conditions, education level and type, and region of birth, and we use the estimated coefficients from 1991 to for the predictions. The predictions for this year correctly predict welfare benefit receipt in 86 percent of cases.
} 
parents and older siblings would be positively correlated, and we would again risk understating the effect of parental welfare benefit receipt.

A third issue to keep in mind when interpreting the results is that by construction, the sibling sample will not include the most severe cases of parental welfare benefit receipt, i.e., those in which parents receive welfare benefits year after year. This is because, as described in the previous section, the sibling sample only includes families that received no welfare benefits until the older sibling was 24 years old and the younger sibling was 16 years old. The effect that is captured by estimating our DID-specification is hence the effect of being exposed to parental welfare benefits in the late teenage years but not before that. Because the larger share of welfare caseloads are in fact made up of shorter spells $^{16}$, this is an interesting group to study. It is however important to keep in mind that the results may be different in families that are dependent on welfare benefits over longer periods of time.

\section{Descriptive analysis}

Before the estimation of the sibling-based DID-analysis of the causal intergenerational effects, we will start by providing a detailed description of the intergenerational pattern of welfare benefit receipt, using data on all individuals born in years 1981-83 and their parents. This means that we use the full cohorts born in the same years as the younger siblings of the sibling analysis. For these cohorts, we observe a large number of household level socio-economic factors starting from age 9.

The reason for starting off with a descriptive section is partly that we think that the intergenerational correlations that are estimated using our large set of data and covariates are interesting in themselves and partly that they can be useful for comparison with other studies.

A first look at the raw data reveals that children's welfare use is much higher if their parents received welfare benefits as the child grew up: 15.0 percent of all children whose parents received welfare at any point while the child was 9-19 years of age, received welfare themselves at the age of 24 , compared to 2.8 percent in families in which the parents received no welfare. The risk that the child received welfare benefits

\footnotetext{
${ }^{16}$ Dahlberg et al. (2008) show that only a small share of the total welfare case load is made up by individuals who remain on welfare year after year.
} 
at age 24 further increases with the share of years that the parents received welfare benefits: among children whose parents received welfare during up to half of the years during the period, approximately 14 percent received welfare themselves at age 24 , while among those whose parents received welfare more than three quarters of the years, the share of welfare benefit recipients is almost the double, 26 percent.

This correlation can, however, stem either from the welfare use itself or from other factors. Table 2 therefore shows the results from estimating the regression equation (1), where we condition on our observable background information on cohorts 1981-83. The results in Table 2 show how welfare benefit receipt at the age of 24 correlates with exposure to parental welfare participation when the child is 9-19 years old, which is defined in column (1), as a dummy for whether the household received welfare benefits at any point in time during this period; in column (2), as the share of years the household received welfare; and, in column (3), as the average annual amount of welfare received during the period. The dependent variable, child welfare use as a young adult, is defined as a dummy that equals one if the household received welfare benefits at the age of $24 .^{17}$

The regressions in Table 2 contain a large set of household-level and parental background covariates, as well as the municipal unemployment rate facing the child as an adult. ${ }^{18}$ Table 2 only shows the results for the variable of main interest, parental welfare, but the full results can be found in the appendix, Table A 1.

\footnotetext{
${ }^{17}$ Note that only children who no longer live with their parents at age 24 are included in the sample.

${ }^{18}$ Household disposable income is included in the set of household level variables in the specification of column (2). Whether or not this variable should be included can be discussed, since having a lower income can be seen as an inherent part of being a recipient of welfare. We have chosen to include the variable since we want to isolate the rolemodel-; net-work-; and attitude-related effects of exposure to parental welfare benefits. It should however be pointed out that excluding disposable income from the regressions does not affect the results for parental welfare benefit receipt.
} 
Table 2 LPM for parental welfare use and child welfare use

\begin{tabular}{lccc}
\hline & \multicolumn{2}{c}{ Child welfare dummy variable at age 24 } \\
\hline & $(1)$ & $(2)$ & $(3)$ \\
\hline Parental welfare dummy 9-19 & $0.066^{* * *}$ & & \\
& $(0.002)$ & & \\
Parental welfare share of years 9-19 & & $0.201^{* * *}$ & \\
& & $(0.006)$ & $0.00155^{* * *}$ \\
Parental welfare/year 9-19 (1000 SEK) & & & $(0.000)$ \\
\hline Household level covariates & Yes & Yes & Yes \\
Municipality fixed effects ${ }^{\alpha}$ & No & No & Yes \\
\hline Observations & 182,200 & 182,200 & 182,200 \\
R-squared & 0.064 & 0.072 & 0.065
\end{tabular}

Robust standard errors in parentheses. $*, * *$ and $* * *$ denote statistical significance at the 10,5 and 1 percent levels respectively.

${ }^{\ltimes}$ Municipality fixed effects are included in the regression using the average yearly amount of welfare benefits received as the child is 9-19, to control for the fact that cost of living, especially housing, differs between municipalities. This affects the amounts of welfare benefits granted.

The results in Table 3 suggest that parental welfare benefit receipt is positively correlated with children's welfare use as young adults after we control for a large number of household level characteristics and the local unemployment rate measured at age 24 of the child. The coefficient in column (1) indicates that growing up in a household that receives welfare benefits at any point during ages 9-19, is correlated with a 6.6 percentage point increase in the probability to receive welfare as a young adult; in addition, the coefficient in column (2) suggests that an increase in the share of the years that the parents received welfare benefits while the child was 9-19 from zero to 100 percent, is correlated with a 20 percentage point increase in the same probability. The coefficient in column (3) indicates that a 1000 SEK increase in parent's annual average welfare benefit is correlated with less than a 0.002 percentage point increase in the welfare probability of the child as an adult.

Table 3 shows the results for the same regression specification as in Table 2 but shows the estimated coefficients for parental welfare receipt when the child was 9-12 years, 13-16 years and 17-19 years separately. This is interesting both as an indication of at which age the intergenerational correlation is the strongest, and as an indication of whether using exposure to parental welfare benefits in the late teens, as we do in the 
sibling-analysis, is reasonable. (The results for the full set of covariates can be found in Table A 2, in the appendix.)

Table 3 LPM for parental welfare at different ages and child welfare use

(1)

(2)

(3)

\begin{tabular}{lc}
\hline Parental welfare 9-12 & $0.030 * * *$ \\
& $(0.003)$ \\
& $0.028^{* * *}$ \\
Parental welfare 13-16 & $(0.003)$ \\
Parental welfare 17-19 & $0.091 * * *$ \\
& $(0.004)$
\end{tabular}

Parental welfare share of years 9-12

Parental welfare share of

Parental welfare share of

Parental welfare/year 9-12

Parental welfare/year 13-16

Household level covariates

Yes

No

Municipal fixed effects

175,861

0.071

R-squared

Robust standard errors in parentheses. *,** and *** denote statistical significance at the 10,5 and 1 percent levels respectively

Municipality fixed effects are included in the regression using the average yearly amount of welfare benefits, to control for the fact that cost of living, especially housing, differs between municipalities. This affects the amounts of welfare benefits granted.

As shown in Table 3, the correlation between parental and child welfare participation is the strongest if the parents received welfare benefits when the child was a teenager: the coefficients in all specifications are statistically significantly larger for exposure to parental welfare when the child is 17-19 years old compared with the younger age intervals. The estimated coefficients in column (1) suggest that parental welfare benefits 
is correlated with a 9 percentage point increase in the probability that the child received welfare benefits at age 24 if measured when the child is 17-19 years old, compared to an approximately 3 percentage point increase when the child is 13-16, and 9-12, respectively. A similar pattern is given for the alternative measures in column (2) and (3). The stronger correlation in the late teens might be due to for example role-model or net-work related effects being particularly strong at these formative years.

Therefore, our descriptive analysis shows that even after conditioning on a large set of household-level covariates, there is a strong positive intergenerational correlation in welfare benefit receipt in our data. We have also observed that this correlation is stronger for parental welfare spells that occur during the late teenage years of the children. Taken together, this suggests that it is interesting to study the causal effects of parental welfare receipt, especially during the late teens, which is what we will do in the sibling-analysis in the following section.

\section{$5 \quad$ Estimating the causal effects using a sibling comparison approach}

To test whether the positive correlations that were estimated in the previous section in fact reflect a causal relationship between parental and child welfare benefit receipt, we turn to the estimation of the sibling DID-regression in equations (2)-(3). The results are presented in Table 4. The specification in column (1) includes only family fixed effects and a dummy variable for being a young sibling, in addition to the main explanatory variable. In column 2, we include parental characteristics, local unemployment and the interaction between coming from a welfare receiving family and local unemployment. In column 3, we exclude the interaction with local unemployment but instead include an interaction between a set of predetermined parental background characteristics ${ }^{19}$ correlated with welfare benefit use and the time dummy variable (i.e., if the sibling is young). Finally, column 4 combines all covariates from column 2 and 3 . This specification corresponds to equation (3).

For comparison, we have added an additional column (column 5), which contains the results obtained when we run the OLS correlation regression of equation (1) using only

\footnotetext{
${ }^{19}$ Parents' country of birth, indicators for whether the father or mother were unemployed at any time during 1985-1990, indicators for the education level of the father and mother (primary school, high school and college) and an indicator for the mother being single any time during 1985-1990.
} 
the sample of younger siblings that are included in the sibling analysis. ${ }^{20}$ As shown in column 5, these results are fairly similar to the results obtained when we used the entire cohorts in Table 3 and Table $4 .^{21}$

The coefficients for the three different measures of parental welfare benefit receipt during ages 17-19 are shown in panels $A-C$; parental welfare at any time is shown in panel $A$; share of years with welfare in panel $B$; and the amount of welfare benefits in panel $C$. (The results for the full set of covariates can be found in Table A 3, Table A 4, and Table A 5 in the Appendix.)

\footnotetext{
${ }^{20}$ Note that the older siblings are not included in this regression, since the parents' welfare receipt is zero for all of the older siblings and there is hence no identifying variation among them to use to identify effects of parental welfare benefits. In the sibling-DID they are however needed as an untreated control group.

${ }^{21}$ The full set of results for the correlations in column 5 can be obtained from the authors upon request.
} 
Table 4 Sibling fixed effects model for parental welfare and child welfare use at the age of 24

Child welfare at 24

Sibling fixed effects model

Correlation young siblings

(1) (2) (3) (4)

\section{Explanatory variable A:}

Parental welfare during ages $17-$

$\begin{array}{ccccc}-0.061 & -0.025 & -0.048 & -0.016 & 0.094 * * \\ (0.037) & (0.060) & (0.037) & (0.060) & (0.026) \\ 0.02 & 0.02 & 0.03 & 0.03 & 0.04\end{array}$

R-squared

$\begin{array}{ccccc}-0.144 & -0.113 & -0.124 & -0.101 & 0.179 * * \\ (0.077) & (0.105) & (0.076) & (0.106) & (0.052) \\ 0.02 & 0.03 & 0.03 & 0.03 & 0.04\end{array}$

R-squared

$\begin{array}{ccccc}0.001 & 0.003 & 0.002 & 0.003 & 0.007 * * \\ (0.004) & (0.004) & (0.004) & (0.004) & (0.002) \\ 0.07 & 0.08 & 0.08 & 0.08 & 0.09\end{array}$

Dummy variable young sibling

Yes

Yes

Yes

Yes

Family fixed effects

Yes

Yes

Yes

Yes

Household level covariates and

local unemployment at age 24

No

Yes

Yes

Yes

Yes $^{\dagger}$

Interactions household

characteristics*young

No

No

Yes

Yes

No

Interaction loca

unemployment*welfare family

No

Yes

No

Yes

No

Observations

9797

9797

9797

9797

4781

Number of groups

$4615 \quad 4615$

4615

4615

Robust standard errors in parentheses. *,** and *** denote statistical significance at the 10,5 and 1 percent levels respectively. All regressions with parental welfare/year as explanatory variable include municipal fixed effects at age 19.

${ }^{\dagger}$ The household level covariates in column (5) also include the time invariant variables that are naturally excluded in the fixed effects analysis.

As shown in column (1) in Table 4, the effect of parental welfare becomes negative and insignificant for parental welfare measures $A$ and $B$, and becomes positive and insignificant for measure $C$, as we control for unobserved family level heterogeneity by including sibling fixed effects in the regressions. For the two former measures, $A$ and $B$, of parental welfare, the coefficient size further decreases as we add additional covariates to the regression, in specifications (2)-(4). For the third measure, average yearly amounts of parental welfare benefits, the coefficient is instead larger when additional 
covariates are included but is also always insignificant. The coefficient of our preferred specification in column 4 , using the parental welfare dummy variable in panel $A$, is fairly close to zero but is imprecisely estimated. ${ }^{22}$

Among the control variables (displayed in Appendix A), we find that the age of the father at immigration has a significant positive effect on the risk of receiving welfare benefits as an adult. The local unemployment rate also seems to be an important factor: a one percentage point increase in the local unemployment level is associated with 7-9 percent increase in the probability of receiving welfare. Finally, on average, the younger siblings have a 3.5-3.8 percentage point lower risk of using welfare benefits as an adult, which is consistent with the general decreasing trend in welfare benefit levels during the first half of the 2000s, as was indicated in Figure 1.

The overall picture that emerges from the sibling analysis is hence that including a family fixed effect in welfare use eliminates the positive correlation between children's and parents' welfare benefit receipt that was found in the initial correlation analysis. As suggested by our use of predicted values for welfare benefit receipt for the period 198589 , this result does not seem to be driven by a negative bias due to unobserved early welfare use.

The results suggest that the large and positive intergenerational correlation in welfare benefit receipt that was observed in the descriptive analysis, especially when parents received welfare benefits in the child's late teens, was not due to the welfare benefit receipt per se, but rather to unobservable factors correlated with welfare benefit receipt. It is interesting to note that this is consistent with the findings of Stenberg (2000), who reports evidence of positive intergenerational correlations in welfare benefit receipt only when other social problems that are usually not observable to the researcher, such as behavioral problems in school or having a father with a criminal record, were present.

There are, however, a couple of potential alternative explanations for the insignificant results of the sibling analysis that should be noted.

\footnotetext{
${ }^{22}$ It can be noted that the estimations in Table 5 were calculated using only families for which we do have information on the set of predetermined variables, observed in 1985-90, which are used to create the time trends in estimations column (3) and (4). When we rerun the regressions in column (1) and (2) using the full sample of siblings, we find that the point estimate of specification (1) goes from being marginally insignificant and negative, to being significant and negative, while the point estimate of specification (2) is negative and insignificant, as in Table 6. The major difference between the two samples is that the sample used in the main analysis does not include families in which the father and/or mother immigrated later than 1985.
} 
First, as discussed in section 3, the estimates in Table 4 are identified using only the families in which the parents did not receive welfare benefits until the younger sibling turned 17. The results shall hence be interpreted as the effects of temporary parental welfare spells when the children are in their late teens, on children's welfare participation. We cannot rule out that the effects are different for longer spells of parental welfare benefit receipt, or that the effect might be different for younger children.

Second, as also noted in section 3, the welfare benefit receipt of both the parents and the older siblings could be correlated with some latent variable that affects the welfare benefit receipt among the older siblings before it affects that of the parents. This would lead to the coefficient being biased towards zero.

Third, our sample size is admittedly small; when restricting the sample to only include siblings that meet the requirement for our sibling-based analysis, we are left with 180 families that received welfare. We cannot therefore rule out that the results reflect a lack of variation in our sample. However, the cross-sectional OLS-results in column (5) of Table 4 are statistically significant and are also similar in size to the estimates in the analysis using the full 1981-1983 cohorts in section 4, so the sibling sample is at least rich enough to detect the same correlation pattern as when using the full data set.

Finally, it is worth mentioning that our results are similar to the results in Ekhaugen (2009), who finds positive correlations in unemployment between parents and children when not accounting for unobserved family heterogeneity but negative, albeit insignificant, effects as sibling-fixed effects are included.

\section{Conclusions}

To conclude, the results of our study suggest that children who grow up in households in which the parents received welfare benefits are themselves more likely to receive welfare benefits. This correlation increases with the period spent on welfare by the parents and is present also when we control for a number of household socio-economic controls. Using the sibling comparison approach to identify causal effects, we cannot, however, refute the zero hypothesis of no relationship between parental welfare use and child welfare participation. This suggests that the positive relationship found in the 
descriptive analysis was driven by other factors than by welfare use per se. These results are consistent with the previous literature on welfare benefit transmission, which has generally found no or weakly positive evidence of causal intergenerational welfare benefit transmission. 


\section{References:}

Airio, I. \& Moisio, P. \& Niemelä, M. (2005), “The Intergenerational Transmission of Poverty in Finland in the 1990s", European Journal of Social Security, vol. 7(3), pp. 251-267.

Antel, J. (1992), “The Intergenerational Transfer of Welfare Dependency: Some Statistical Evidence", Review of Economics and Statistics, vol. 74, no 3, pp. 467473.

Ashenfelter, O. \& Zimmernman, D. (1997), "Estimates of the Returns to Schooling from Sibling Data: Fathers, Sons, and Brothers", The Review of Economics and Statistics, vol. 79(1), pp. 1-9

Chadwick, L. \& Solon, G. (2002) "Intergenerational Income Mobility among Daughters," American Economic Review, vol. 92(1) pp. 335-344.

Corak, M. \& Heisz, A. (1999), "The intergenerational earnings and income mobility of Canadian men: Evidence from longitudinal income tax data", The Journal of Human Resources, vol. 34(33), pp. 504-533.

Dahlberg, M., Edmark K., Hansen, J. \& Mörk, E. (2008), "Fattigdom i folkhemmet. SNS Välfärdsråds rapport 2008.” SNS.

Duncan, G. J., Yeung, W. J., Brooks-Gunn, J. \& Smith, J.R. (1998), “How Much Does Childhood Poverty Affect the Life Chances of Children?" American Sociological Review, vol. 63, pp. 406-423.

Ekhaugen, T. (2009), "Extracting the causal component from the intergenerational correlation in unemployment”, Journal of Population Economics, vol. 22, pp. 97-113.

Gottschalk, P. (1990), “AFDC Participation Across Generations”, American Economic Review, vol. 80(2), pp.367-371.

Gottschalk, P. (1996), "Is the correlation on Welfare Participation Across Generations Spurious", Journal of Public Economics, vol. 63, pp.1-25.

Hansen, J. \& Löfström, M. (2003), “Immigrant Assimilation and Welfare Participation: Do Immigrants Assimilate Into or Out of Welfare?" The Journal of Human Resources, vol. 38, pp. 74-98. 
Levine, P. \& Zimmerman, D. (2005), “Children's welfare exposure and subsequent development”, Journal of Public Economics, vol. 89, pp. 31- 56.

Maloney, T., Maani, S. \& Pacheco, G. (2003), "Intergenerational Welfare Participation in New Zealand”, Australian Economic Papers, vol. 42, pp. 346-362.

Pepper, J. (2000), “The Intergenerational Transmission of Welfare Receipt: A Nonparametric Bounds Analysis", The Review of Economics and Statistics, vol. 82(3), pp. 472-488.

Siedler, T. (2004), "Is the receipt of social assistance transmitted from parents to children? Evidence from German panel data”, unpublished paper, Institute for Social and Economic Research, University of Essex.

Solon, G. (1992), "Intergenerational Income Mobility in the United States," American Economic Review, vol. 82(3), pp. 393-408.

Stenberg, S. (2000) "Inheritance of Welfare Recipiency: An Intergenerational Study of Social AssistanceRecipiency in Postwar Sweden", Journal of Marriage and the Family, vol. 62(1), pp. 228-239. 


\section{Appendix A: Supplementary descriptive statistics and estimates}

Table A 1 LPM for parental welfare use and child welfare use

\begin{tabular}{|c|c|c|c|}
\hline & \multicolumn{3}{|c|}{ Child welfare at 24} \\
\hline VARIABLES & (1) & (2) & (3) \\
\hline \multirow[t]{2}{*}{ Parental welfare during ages 9-19 } & $0.0655 * * *$ & & \\
\hline & $(0.00188)$ & & \\
\hline \multirow[t]{2}{*}{ Parental welfare share of years ages 9-19 } & & $0.201 * * *$ & \\
\hline & & $(0.00552)$ & \\
\hline \multirow[t]{2}{*}{ Parental welfare yearly amount ages 9-19 } & & & $0.00155 * * *$ \\
\hline & & & $(8.66 \mathrm{e}-05)$ \\
\hline \multirow[t]{2}{*}{ Sickness benefits mother share of years 9-19 } & $0.0356 * * *$ & $0.0374 * * *$ & $0.0540 * * *$ \\
\hline & $(0.00299)$ & $(0.00297)$ & $(0.00300)$ \\
\hline \multirow[t]{2}{*}{ Sickness pension mother share of years 9-19 } & -0.00343 & $0.00842 *$ & 0.00369 \\
\hline & $(0.00450)$ & $(0.00447)$ & $(0.00451)$ \\
\hline \multirow[t]{2}{*}{ Disability pension mother share of years 9-19 } & 0.00648 & 0.00909 & 0.00427 \\
\hline & $(0.0109)$ & $(0.0108)$ & $(0.0108)$ \\
\hline \multirow[t]{2}{*}{ Sickness benefits father share of years 9-19 } & $0.0264 * * *$ & $0.0318 * * *$ & $0.0392 * * *$ \\
\hline & $(0.00339)$ & $(0.00337)$ & $(0.00340)$ \\
\hline \multirow[t]{2}{*}{ Sickness pension father share of years 9-19 } & 0.00459 & $0.0149 * * *$ & $0.0130 * *$ \\
\hline & $(0.00559)$ & $(0.00555)$ & $(0.00560)$ \\
\hline \multirow[t]{2}{*}{ Disability pension father share of years 9-19 } & -0.00713 & -0.00849 & -0.00645 \\
\hline & $(0.0107)$ & $(0.0105)$ & $(0.0106)$ \\
\hline \multirow[t]{2}{*}{ Mother not employed share of years 9-19 } & $0.0522 * * *$ & $0.0262 * * *$ & $0.0559 * * *$ \\
\hline & $(0.00287)$ & $(0.00285)$ & $(0.00288)$ \\
\hline \multirow[t]{2}{*}{ Father not employed share of years 9-19 } & $0.0543 * * *$ & $0.0343 * * *$ & $0.0499 * * *$ \\
\hline & $(0.00352)$ & $(0.00355)$ & $(0.00357)$ \\
\hline \multirow[t]{2}{*}{ Mother finished high school at age 19} & $-0.0124 * * *$ & $-0.00814 * * *$ & $-0.0111 * * *$ \\
\hline & $(0.00174)$ & $(0.00173)$ & $(0.00174)$ \\
\hline \multirow[t]{2}{*}{ Mother finished college at age 19} & $-0.0143 * * *$ & $-0.0106 * * *$ & $-0.0161 * * *$ \\
\hline & $(0.00181)$ & $(0.00180)$ & $(0.00182)$ \\
\hline \multirow[t]{2}{*}{ Father finished high school at age 19} & 0.00152 & 0.00198 & 0.000900 \\
\hline & $(0.00139)$ & $(0.00138)$ & $(0.00140)$ \\
\hline \multirow[t]{2}{*}{ Father finished college at age 19} & -0.000464 & -0.00107 & $-0.00339 * *$ \\
\hline & $(0.00150)$ & $(0.00149)$ & $(0.00153)$ \\
\hline \multirow[t]{2}{*}{$\begin{array}{l}\text { Disposable family income total 9-19 } \\
\text { (1 000 000's of SEK) }\end{array}$} & $-3.15 \mathrm{e}-10 * * *$ & $-4.04 \mathrm{e}-10 * * *$ & $-1.76 \mathrm{e}-07 *$ \\
\hline & $(1.03 \mathrm{e}-10)$ & $(1.15 \mathrm{e}-10)$ & $(1.01 \mathrm{e}-07)$ \\
\hline
\end{tabular}




\begin{tabular}{|c|c|c|c|}
\hline & \multicolumn{3}{|c|}{ Child welfare at 24} \\
\hline VARIABLES & (1) & (2) & (3) \\
\hline \multirow[t]{2}{*}{ Single mother share of years $9-19$} & $0.0319 * * *$ & $0.0283 * * *$ & $0.0465 * * *$ \\
\hline & $(0.00232)$ & $(0.00230)$ & $(0.00231)$ \\
\hline \multirow[t]{2}{*}{ Divorce during ages 9-19 } & $0.0107 * * *$ & $0.0124 * * *$ & $0.0162 * * *$ \\
\hline & $(0.00193)$ & $(0.00192)$ & $(0.00193)$ \\
\hline \multirow[t]{2}{*}{ Nr children $0-17$ in the household at age 19} & $0.00342 * * *$ & $0.00169 * *$ & $0.00266 * * *$ \\
\hline & $(0.000736)$ & $(0.000732)$ & $(0.000736)$ \\
\hline \multirow[t]{2}{*}{ Mother born in Nordic country } & 0.00494 & $0.0114 * * *$ & $0.0107 * * *$ \\
\hline & $(0.00354)$ & $(0.00353)$ & $(0.00358)$ \\
\hline \multirow[t]{2}{*}{ Mother born in Western country } & -0.00330 & 0.00523 & 0.00291 \\
\hline & $(0.00603)$ & $(0.00596)$ & $(0.00601)$ \\
\hline \multirow[t]{2}{*}{ Mother born in East Europe } & -0.00620 & -0.00795 & -0.00864 \\
\hline & $(0.00619)$ & $(0.00616)$ & $(0.00620)$ \\
\hline \multirow[t]{2}{*}{ Mother born outside Europe/Western country } & -0.000939 & -0.00801 & -0.00650 \\
\hline & $(0.00678)$ & $(0.00676)$ & $(0.00681)$ \\
\hline \multirow[t]{2}{*}{ Father born in Nordic country } & 0.00531 & $0.0128 * * *$ & $0.0127 * * *$ \\
\hline & $(0.00379)$ & $(0.00378)$ & $(0.00381)$ \\
\hline \multirow[t]{2}{*}{ Father born in Western country } & -0.00508 & 0.00476 & 0.00320 \\
\hline & $(0.00496)$ & $(0.00495)$ & $(0.00498)$ \\
\hline \multirow[t]{2}{*}{ Father born in East Europe } & $-0.0147 * *$ & $-0.0170 * * *$ & $-0.0147 * *$ \\
\hline & $(0.00611)$ & $(0.00608)$ & $(0.00611)$ \\
\hline \multirow[t]{2}{*}{ Father born outside Europe/Western country } & -0.00680 & -0.00302 & 0.00233 \\
\hline & $(0.00636)$ & $(0.00634)$ & $(0.00638)$ \\
\hline \multirow[t]{2}{*}{ Mother's age at child's birth } & $-0.00100 * * *$ & $-0.00102 * * *$ & $-0.00114 * * *$ \\
\hline & $(0.000134)$ & $(0.000134)$ & $(0.000135)$ \\
\hline \multirow{2}{*}{ Mother's age at immigration } & $-8.64 \mathrm{e}-05$ & $-0.000372 * *$ & -0.000218 \\
\hline & $(0.000145)$ & $(0.000144)$ & $(0.000146)$ \\
\hline \multirow[t]{2}{*}{ Father's age at immigration } & $0.000271 * *$ & $-8.77 \mathrm{e}-05$ & $4.26 \mathrm{e}-06$ \\
\hline & $(0.000130)$ & $(0.000130)$ & $(0.000131)$ \\
\hline \multirow[t]{2}{*}{ Local unemployment at age 24 of child } & $0.00106^{* * *}$ & $0.00104 * * *$ & 0.000395 \\
\hline & $(0.000278)$ & $(0.000277)$ & $(0.000280)$ \\
\hline \multirow[t]{2}{*}{ Constant } & $0.0357 * * *$ & $0.0397 * * *$ & $0.0577 * * *$ \\
\hline & $(0.00453)$ & $(0.00451)$ & $(0.0104)$ \\
\hline Municipality fixed effects & No & No & Yes \\
\hline Observations & 182,200 & 182,200 & 182,200 \\
\hline R-squared & 0.064 & 0.072 & 0.065 \\
\hline
\end{tabular}

Robust standard errors in parentheses, $* * * \mathrm{p}<0.01, * * \mathrm{p}<0.05, * \mathrm{p}<0.1$ 
Table A 2 LPM for parental welfare use and child welfare use different ages

\begin{tabular}{|c|c|c|c|}
\hline \multirow[t]{2}{*}{ VARIABLES } & \multicolumn{3}{|c|}{ Child welfare at 24} \\
\hline & (1) & (2) & (3) \\
\hline \multirow[t]{2}{*}{ Parental welfare during ages $9-12$} & $0.0302 * * *$ & & \\
\hline & $(0.00263)$ & & \\
\hline \multirow[t]{2}{*}{ Parental welfare during ages $13-16$} & $0.0284 * * *$ & & \\
\hline & $(0.00273)$ & & \\
\hline \multirow[t]{2}{*}{ Parental welfare during ages $17-19$} & $0.0905 * * *$ & & \\
\hline & $(0.00360)$ & & \\
\hline \multirow[t]{2}{*}{ Parental welfare share of years ages 9-12 } & & $0.0574 * * *$ & \\
\hline & & $(0.00552)$ & \\
\hline \multirow[t]{2}{*}{ Parental welfare share of years ages 13-16 } & & $0.0422 * * *$ & \\
\hline & & $(0.00598)$ & \\
\hline \multirow[t]{2}{*}{ Parental welfare share of years ages 17-19 } & & $0.135 * * *$ & \\
\hline & & $(0.00668)$ & \\
\hline \multirow[t]{2}{*}{ Parental welfare yearly amount ages 9-12 } & & & $0.000710 * * *$ \\
\hline & & & $(0.000133)$ \\
\hline \multirow[t]{2}{*}{ Parental welfare yearly amount ages 13-16 } & & & 0.000214 \\
\hline & & & $(0.000152)$ \\
\hline \multirow[t]{2}{*}{ Parental welfare yearly amount ages 17-19 } & & & $0.00198 * * *$ \\
\hline & & & $(0.000204)$ \\
\hline \multirow[t]{2}{*}{ Sickness benefits mother share of years 9-12 } & $0.0125 * * *$ & $0.0143 * * *$ & $0.0196 * * *$ \\
\hline & $(0.00217)$ & $(0.00217)$ & $(0.00218)$ \\
\hline \multirow[t]{2}{*}{ Sickness benefits mother share of years 13-16 } & $0.00678 * *$ & $0.00799 * * *$ & $0.0162 * * *$ \\
\hline & $(0.00302)$ & $(0.00302)$ & $(0.00303)$ \\
\hline \multirow[t]{2}{*}{ Sickness benefits mother share of years 17-19 } & $0.0111 * * *$ & $0.0124 * * *$ & $0.0172 * * *$ \\
\hline & $(0.00208)$ & $(0.00208)$ & $(0.00209)$ \\
\hline \multirow[t]{2}{*}{ Sickness pension mother share of years $9-12$} & 0.00410 & 0.00913 & 0.00803 \\
\hline & $(0.00845)$ & $(0.00843)$ & $(0.00850)$ \\
\hline \multirow[t]{2}{*}{ Sickness pension mother share of years 13-16 } & -0.00423 & -0.00227 & -0.00255 \\
\hline & $(0.00850)$ & $(0.00849)$ & $(0.00855)$ \\
\hline \multirow[t]{2}{*}{ Sickness pension mother share of years 17-19 } & 0.00288 & 0.00299 & 0.00269 \\
\hline & $(0.00550)$ & $(0.00550)$ & $(0.00551)$ \\
\hline \multirow[t]{2}{*}{ Disability pension mother share of years $9-12$} & 0.0404 & 0.0412 & 0.0396 \\
\hline & $(0.0266)$ & $(0.0267)$ & $(0.0267)$ \\
\hline \multirow[t]{2}{*}{ Disability pension mother share of years 13-16 } & 0.00403 & 0.00132 & -0.00166 \\
\hline & $(0.0340)$ & $(0.0340)$ & $(0.0341)$ \\
\hline Disability pension mother share of years $17-19$ & -0.0258 & -0.0236 & -0.0244 \\
\hline
\end{tabular}




\begin{tabular}{|c|c|c|c|}
\hline \multirow[t]{2}{*}{ VARIABLES } & \multicolumn{3}{|c|}{ Child welfare at 24} \\
\hline & (1) & (2) & (3) \\
\hline & $(0.0199)$ & $(0.0200)$ & $(0.0199)$ \\
\hline \multirow[t]{2}{*}{ Sickness benefits father share of years $9-12$} & $0.0147 * * *$ & $0.0162 * * *$ & $0.0192 * * *$ \\
\hline & $(0.00231)$ & $(0.00231)$ & $(0.00231)$ \\
\hline \multirow[t]{2}{*}{ Sickness benefits father share of years 13-16 } & 0.00446 & 0.00544 & $0.00924 * * *$ \\
\hline & $(0.00346)$ & $(0.00346)$ & $(0.00348)$ \\
\hline \multirow[t]{2}{*}{ Sickness benefits father share of years 17-19 } & $0.00762 * * *$ & $0.00830 * * *$ & $0.00952 * * *$ \\
\hline & $(0.00256)$ & $(0.00256)$ & $(0.00257)$ \\
\hline \multirow[t]{2}{*}{ Sickness pension father share of years $9-12$} & $0.0278 * * *$ & $0.0317 * * *$ & $0.0372 * * *$ \\
\hline & $(0.0103)$ & $(0.0102)$ & $(0.0103)$ \\
\hline \multirow[t]{2}{*}{ Sickness pension father share of years 13-16 } & $-0.0177 *$ & $-0.0166 *$ & $-0.0199 * *$ \\
\hline & $(0.0101)$ & $(0.0101)$ & $(0.0101)$ \\
\hline \multirow[t]{2}{*}{ Sickness pension father share of years 17-19 } & 0.00630 & 0.00467 & 0.00509 \\
\hline & $(0.00686)$ & $(0.00685)$ & $(0.00689)$ \\
\hline \multirow[t]{2}{*}{ Disability pension father share of years $9-12$} & 0.0204 & 0.0225 & 0.0239 \\
\hline & $(0.0252)$ & $(0.0252)$ & $(0.0247)$ \\
\hline \multirow[t]{2}{*}{ Disability pension father share of years 13-16 } & $-0.0549 *$ & -0.0545 & $-0.0538 *$ \\
\hline & $(0.0332)$ & $(0.0334)$ & $(0.0324)$ \\
\hline \multirow[t]{2}{*}{ Disability pension father share of years 17-19 } & 0.0192 & 0.0175 & 0.0174 \\
\hline & $(0.0244)$ & $(0.0246)$ & $(0.0239)$ \\
\hline \multirow[t]{2}{*}{ Mother not employed share of years 9-12 } & $0.0139 * * *$ & $0.0113 * * *$ & $0.0196 * * *$ \\
\hline & $(0.00292)$ & $(0.00292)$ & $(0.00295)$ \\
\hline \multirow[t]{2}{*}{ Mother not employed share of years 13-16 } & $0.00693 * *$ & $0.00616 *$ & $0.0154 * * *$ \\
\hline & $(0.00332)$ & $(0.00332)$ & $(0.00334)$ \\
\hline \multirow[t]{2}{*}{ Mother not employed share of years $17-19$} & $0.0140 * * *$ & $0.00948 * * *$ & $0.0168 * * *$ \\
\hline & $(0.00315)$ & $(0.00314)$ & $(0.00314)$ \\
\hline \multirow[t]{2}{*}{ Father not employed share of years $9-12$} & $0.0123 * * *$ & $0.00995 * * *$ & $0.0151 * * *$ \\
\hline & $(0.00372)$ & $(0.00372)$ & $(0.00373)$ \\
\hline \multirow[t]{2}{*}{ Father not employed share of years 13-16 } & $0.0153 * * *$ & $0.0153 * * *$ & $0.0200 * * *$ \\
\hline & $(0.00400)$ & $(0.00400)$ & $(0.00400)$ \\
\hline \multirow[t]{2}{*}{ Father not employed share of years 17-19 } & $0.0133 * * *$ & $0.0120 * * *$ & $0.0139 * * *$ \\
\hline & $(0.00349)$ & $(0.00348)$ & $(0.00349)$ \\
\hline \multirow[t]{2}{*}{ Mother finished high school at age 12 of child } & -0.00322 & -0.00393 & -0.00725 \\
\hline & $(0.00753)$ & $(0.00759)$ & $(0.00754)$ \\
\hline \multirow[t]{2}{*}{ Mother finished college at age 12 of child } & 0.00250 & -0.000481 & -0.00174 \\
\hline & $(0.00811)$ & $(0.00817)$ & $(0.00812)$ \\
\hline Mother finished high school at age 16 of child & 0.000386 & -0.000776 & -0.00158 \\
\hline
\end{tabular}




\begin{tabular}{|c|c|c|c|}
\hline \multirow[t]{2}{*}{ VARIABLES } & \multicolumn{3}{|c|}{ Child welfare at 24} \\
\hline & (1) & (2) & (3) \\
\hline & $(0.00799)$ & $(0.00805)$ & $(0.00801)$ \\
\hline \multirow[t]{2}{*}{ Mother finished college at age 16 of child } & -0.00534 & -0.00713 & -0.00788 \\
\hline & $(0.00941)$ & $(0.00947)$ & $(0.00946)$ \\
\hline \multirow[t]{2}{*}{ Mother finished high school at age 19 of child } & -0.00587 & -0.00292 & -0.00184 \\
\hline & $(0.00392)$ & $(0.00392)$ & $(0.00393)$ \\
\hline \multirow[t]{2}{*}{ Mother finished college at age 19 of child } & -0.00748 & -0.00266 & -0.00580 \\
\hline & $(0.00583)$ & $(0.00584)$ & $(0.00588)$ \\
\hline \multirow[t]{2}{*}{ Father finished high school at age 12 of child } & $0.0342 * * *$ & $0.0342 * * *$ & $0.0328 * * *$ \\
\hline & $(0.0114)$ & $(0.0115)$ & $(0.0115)$ \\
\hline \multirow[t]{2}{*}{ Father finished college at age 12 of child } & 0.0172 & 0.0147 & 0.0138 \\
\hline & $(0.0130)$ & $(0.0130)$ & $(0.0130)$ \\
\hline \multirow[t]{2}{*}{ Father finished high school at age 16 of child } & $-0.0305 * *$ & $-0.0312 * *$ & $-0.0324 * * *$ \\
\hline & $(0.0124)$ & $(0.0125)$ & $(0.0125)$ \\
\hline \multirow[t]{2}{*}{ Father finished college at age 16 of child } & -0.00394 & -0.00238 & -0.00658 \\
\hline & $(0.0149)$ & $(0.0149)$ & $(0.0149)$ \\
\hline \multirow[t]{2}{*}{ Father finished high school at age 19 of child } & -0.000314 & 0.000423 & 0.00204 \\
\hline & $(0.00522)$ & $(0.00522)$ & $(0.00518)$ \\
\hline \multirow[t]{2}{*}{ Father finished college at age 19 of child } & -0.0122 & -0.0118 & -0.00907 \\
\hline & $(0.00767)$ & $(0.00765)$ & $(0.00772)$ \\
\hline \multirow{2}{*}{$\begin{array}{l}\text { Disposable family income total 9-12 } \\
(1000000 \text { 's of SEK) }\end{array}$} & $1.72 \mathrm{e}-10$ & $2.79 \mathrm{e}-10$ & $1.50 \mathrm{e}-06^{* *}$ \\
\hline & $(6.90 \mathrm{e}-10)$ & $(6.93 \mathrm{e}-10)$ & $(7.30 \mathrm{e}-07)$ \\
\hline \multirow{2}{*}{$\begin{array}{l}\text { Disposable family income total 13-16 } \\
\text { (1 000 000's of SEK) }\end{array}$} & $-6.20 \mathrm{e}-10^{*}$ & $-9.23 \mathrm{e}-10 * *$ & $-6.64 \mathrm{e}-07 *$ \\
\hline & $(3.47 \mathrm{e}-10)$ & $(3.78 \mathrm{e}-10)$ & $(3.49 \mathrm{e}-07)$ \\
\hline \multirow{2}{*}{$\begin{array}{l}\text { Disposable family income total 17-19 } \\
\text { (1 000 000's of SEK) }\end{array}$} & $-6.51 \mathrm{e}-07 * *$ & $-6.73 e-07 * *$ & $-0.000646 * *$ \\
\hline & $(2.76 \mathrm{e}-07)$ & $(2.99 \mathrm{e}-07)$ & $(0.000277)$ \\
\hline \multirow[t]{2}{*}{ Single mother share of years $9-12$} & $0.0181 * * *$ & $0.0193 * * *$ & $0.0271 * * *$ \\
\hline & $(0.00408)$ & $(0.00408)$ & $(0.00407)$ \\
\hline \multirow[t]{2}{*}{ Single mother share of years $13-16$} & -0.000125 & $3.17 \mathrm{e}-05$ & 0.00449 \\
\hline & $(0.00480)$ & $(0.00479)$ & $(0.00479)$ \\
\hline \multirow[t]{2}{*}{ Single mother share of years $17-19$} & $0.00685 *$ & 0.00595 & $0.0124 * * *$ \\
\hline & $(0.00403)$ & $(0.00402)$ & $(0.00404)$ \\
\hline \multirow[t]{2}{*}{ Divorce 9-19 } & $0.0110 * * *$ & $0.0136 * * *$ & $0.0180 * * *$ \\
\hline & $(0.00255)$ & $(0.00254)$ & $(0.00256)$ \\
\hline \multirow[t]{2}{*}{ Nr children $0-17$ in the household at age 12} & $-0.00411 * * *$ & $-0.00385 * * *$ & -0.00106 \\
\hline & $(0.000966)$ & $(0.000962)$ & $(0.000969)$ \\
\hline
\end{tabular}




\begin{tabular}{|c|c|c|c|}
\hline \multirow[t]{2}{*}{ VARIABLES } & \multicolumn{3}{|c|}{ Child welfare at 24} \\
\hline & (1) & (2) & (3) \\
\hline \multirow[t]{2}{*}{ Nr children $0-17$ in the household at age 16} & 0.00129 & 0.000715 & $6.17 \mathrm{e}-05$ \\
\hline & $(0.00178)$ & $(0.00178)$ & $(0.00179)$ \\
\hline \multirow[t]{2}{*}{ Nr children $0-17$ in the household at age 19} & 0.00244 & 0.00232 & 0.00207 \\
\hline & $(0.00172)$ & $(0.00171)$ & $(0.00172)$ \\
\hline \multirow[t]{2}{*}{ Mother born in Nordic country } & 0.00553 & $0.00712 * *$ & $0.00847 * *$ \\
\hline & $(0.00359)$ & $(0.00359)$ & $(0.00364)$ \\
\hline \multirow[t]{2}{*}{ Mother born in Western country } & 0.00248 & 0.00421 & 0.00261 \\
\hline & $(0.00618)$ & $(0.00614)$ & $(0.00620)$ \\
\hline \multirow[t]{2}{*}{ Mother born in East Europe } & 0.000881 & 0.000801 & -0.000799 \\
\hline & $(0.00630)$ & $(0.00629)$ & $(0.00634)$ \\
\hline \multirow[t]{2}{*}{ Mother born outside Europe/Western country } & -0.0110 & $-0.0167 * *$ & $-0.0185 * * *$ \\
\hline & $(0.00704)$ & $(0.00705)$ & $(0.00713)$ \\
\hline \multirow[t]{2}{*}{ Father born in Nordic country } & 0.00597 & $0.00879 * *$ & $0.00959 * *$ \\
\hline & $(0.00382)$ & $(0.00382)$ & $(0.00386)$ \\
\hline \multirow[t]{2}{*}{ Father born in Western country } & -0.00194 & 0.00115 & 0.00184 \\
\hline & $(0.00507)$ & $(0.00507)$ & $(0.00511)$ \\
\hline \multirow[t]{2}{*}{ Father born in East Europe } & -0.00727 & -0.00538 & -0.00458 \\
\hline & $(0.00629)$ & $(0.00628)$ & $(0.00630)$ \\
\hline \multirow[t]{2}{*}{ Father born outside Europe/Western country } & -0.00525 & -0.00476 & $3.01 \mathrm{e}-05$ \\
\hline & $(0.00663)$ & $(0.00664)$ & $(0.00669)$ \\
\hline \multirow[t]{2}{*}{ Mother's age at child's birth } & $-0.00107 * * *$ & $-0.00107 * * *$ & $-0.00116 * * *$ \\
\hline & $(0.000137)$ & $(0.000137)$ & $(0.000139)$ \\
\hline \multirow[t]{2}{*}{ Mother's age at immigration } & -0.000155 & -0.000189 & -0.000163 \\
\hline & $(0.000149)$ & $(0.000148)$ & $(0.000151)$ \\
\hline \multirow[t]{2}{*}{ Father's age at immigration } & $0.000245^{*}$ & 0.000142 & 0.000169 \\
\hline & $(0.000136)$ & $(0.000136)$ & $(0.000137)$ \\
\hline \multirow[t]{2}{*}{ Local unemployment at age 24 of child } & $0.000524 *$ & $0.000595 * *$ & 0.000200 \\
\hline & $(0.000276)$ & $(0.000276)$ & $(0.000280)$ \\
\hline \multirow[t]{2}{*}{ Constant } & $0.0454 * * *$ & $0.0468 * * *$ & $0.0620 * * *$ \\
\hline & $(0.00522)$ & $(0.00522)$ & $(0.0109)$ \\
\hline Municipality fixed effects & No & No & Yes \\
\hline Observations & 175,861 & 175,861 & 175,861 \\
\hline R-squared & 0.071 & 0.072 & 0.069 \\
\hline
\end{tabular}

Robust standard errors in parentheses, *** $\mathrm{p}<0.01$, ** $\mathrm{p}<0.05, * \mathrm{p}<0.1$ 
Table A 3 Sibling fixed effects model for parental welfare during ages 17-19 and child welfare use at the age of 24 , siblings born in 1973-75 and 1981-83

\begin{tabular}{|c|c|c|c|c|}
\hline & (1) & (2) & (3) & $(4)$ \\
\hline \multirow[t]{2}{*}{ Parental welfare share of years 17-19 } & -0.061 & -0.025 & -0.048 & -0.016 \\
\hline & $(0.037)$ & $(0.060)$ & $(0.037)$ & $(0.060)$ \\
\hline \multirow[t]{2}{*}{ Young } & $-0.035 * *$ & -0.017 & -0.017 & -0.019 \\
\hline & $(0.004)$ & $(0.012)$ & $(0.047)$ & $(0.047)$ \\
\hline \multirow[t]{2}{*}{ Sickness benefits mother share of years 17-19 } & & 0.001 & 0.000 & 0.001 \\
\hline & & $(0.012)$ & $(0.012)$ & $(0.012)$ \\
\hline \multirow[t]{2}{*}{ Sickness pension mother share of years $17-19$} & & 0.017 & 0.014 & 0.014 \\
\hline & & $(0.024)$ & $(0.024)$ & $(0.024)$ \\
\hline \multirow[t]{2}{*}{ Disability pension mother share of years $17-19$} & & -0.003 & 0.006 & 0.008 \\
\hline & & $(0.049)$ & $(0.051)$ & $(0.052)$ \\
\hline \multirow[t]{2}{*}{ Sickness benefits father share of years 17-19 } & & 0.007 & 0.007 & 0.007 \\
\hline & & $(0.013)$ & $(0.013)$ & $(0.013)$ \\
\hline \multirow[t]{2}{*}{ Sickness pension father share of years $17-19$} & & 0.030 & 0.030 & 0.029 \\
\hline & & $(0.025)$ & $(0.025)$ & $(0.025)$ \\
\hline \multirow[t]{2}{*}{ Disability pension father share of years $17-19$} & & 0.103 & 0.104 & 0.105 \\
\hline & & $(0.077)$ & $(0.077)$ & $(0.077)$ \\
\hline \multirow[t]{2}{*}{ Mother not employed share of years 17-19 } & & -0.029 & -0.032 & -0.031 \\
\hline & & $(0.017)$ & $(0.017)$ & $(0.017)$ \\
\hline \multirow[t]{2}{*}{ Father not employed share of years 17-19 } & & 0.005 & 0.007 & 0.007 \\
\hline & & $(0.018)$ & $(0.018)$ & $(0.018)$ \\
\hline \multirow[t]{2}{*}{ Mother finished high school at age 19} & & -0.034 & -0.044 & -0.043 \\
\hline & & $(0.032)$ & $(0.033)$ & $(0.033)$ \\
\hline \multirow[t]{2}{*}{ Mother finished college at age 19} & & -0.008 & -0.018 & -0.017 \\
\hline & & $(0.044)$ & $(0.044)$ & $(0.044)$ \\
\hline \multirow[t]{2}{*}{ Father finished high school at age 19} & & 0.009 & 0.006 & 0.006 \\
\hline & & $(0.022)$ & $(0.022)$ & $(0.022)$ \\
\hline \multirow[t]{2}{*}{ Father finished college at age 19} & & -0.020 & -0.023 & -0.023 \\
\hline & & $(0.026)$ & $(0.026)$ & $(0.027)$ \\
\hline \multirow{2}{*}{$\begin{array}{l}\text { Disposable family income total 17-19 } \\
\text { (1 000 000's of SEK) }\end{array}$} & & -0.000 & -0.000 & -0.000 \\
\hline & & $(0.002)$ & $(0.002)$ & $(0.002)$ \\
\hline \multirow[t]{2}{*}{ Single mother share of years $17-19$} & & 0.016 & 0.014 & 0.014 \\
\hline & & $(0.018)$ & $(0.018)$ & $(0.018)$ \\
\hline \multirow[t]{2}{*}{ Divorce during ages $17-19$} & & 0.010 & 0.011 & 0.011 \\
\hline & & $(0.022)$ & $(0.022)$ & $(0.022)$ \\
\hline Nr children $0-17$ in the household at age 19 & & 0.002 & 0.001 & 0.001 \\
\hline
\end{tabular}




\begin{tabular}{|c|c|c|c|c|}
\hline & (1) & (2) & (3) & (4) \\
\hline & & $(0.006)$ & $(0.006)$ & $(0.006)$ \\
\hline \multirow[t]{2}{*}{ Father born in Nordic country } & & -0.067 & -0.089 & -0.089 \\
\hline & & $(0.100)$ & $(0.103)$ & $(0.103)$ \\
\hline \multirow[t]{2}{*}{ Father born in Western country } & & -0.003 & -0.007 & -0.011 \\
\hline & & $(0.078)$ & $(0.077)$ & $(0.077)$ \\
\hline \multirow[t]{2}{*}{ Father born in East Europe } & & 0.080 & 0.058 & 0.058 \\
\hline & & $(0.173)$ & $(0.188)$ & $(0.188)$ \\
\hline \multirow[t]{2}{*}{ Father born outside Europe/Western country } & & 0.327 & 0.341 & 0.342 \\
\hline & & $(0.235)$ & $(0.231)$ & $(0.231)$ \\
\hline \multirow[t]{2}{*}{ Age of father at immigration } & & $-0.003 *$ & $-0.004 *$ & $-0.004 *$ \\
\hline & & $(0.001)$ & $(0.002)$ & $(0.002)$ \\
\hline \multirow[t]{2}{*}{ Average local unemployment } & & $0.007 * *$ & $0.008^{* *}$ & $0.008^{*}$ \\
\hline & & $(0.003)$ & $(0.003)$ & $(0.003)$ \\
\hline \multirow[t]{2}{*}{ Local unemployment * welfare family } & & 0.015 & & 0.015 \\
\hline & & $(0.024)$ & & $(0.024)$ \\
\hline \multirow[t]{2}{*}{ Mother born in Nordic country * young } & & & -0.026 & -0.026 \\
\hline & & & $(0.029)$ & $(0.029)$ \\
\hline \multirow[t]{2}{*}{ Mother born in Western country * young } & & & 0.094 & 0.094 \\
\hline & & & $(0.049)$ & $(0.049)$ \\
\hline \multirow[t]{2}{*}{ Mother born in East Europe * young } & & & 0.035 & 0.034 \\
\hline & & & $(0.030)$ & $(0.030)$ \\
\hline \multirow[t]{2}{*}{ Mother born outside Europe/Western country * young } & & & -0.146 & -0.146 \\
\hline & & & $(0.089)$ & $(0.089)$ \\
\hline \multirow[t]{2}{*}{ Father born in Nordic country * young } & & & 0.034 & 0.034 \\
\hline & & & $(0.044)$ & $(0.044)$ \\
\hline \multirow[t]{2}{*}{ Father born in Western country * young } & & & 0.015 & 0.015 \\
\hline & & & $(0.048)$ & $(0.048)$ \\
\hline \multirow[t]{2}{*}{ Father born in East Europe * young } & & & 0.029 & 0.029 \\
\hline & & & $(0.070)$ & $(0.070)$ \\
\hline \multirow[t]{2}{*}{ Father born outside Europe/Western country * young } & & & -0.065 & -0.065 \\
\hline & & & $(0.068)$ & $(0.069)$ \\
\hline \multirow[t]{2}{*}{ Father unemployed during 1985-1990* young } & & & 0.014 & 0.013 \\
\hline & & & $(0.018)$ & $(0.018)$ \\
\hline \multirow[t]{2}{*}{ Father only primary school in $1985-1990 *$ young } & & & -0.009 & -0.008 \\
\hline & & & $(0.010)$ & $(0.010)$ \\
\hline \multirow[t]{2}{*}{ Mother only primary school in $1985-1990 *$ young } & & & $0.022^{*}$ & $0.022 *$ \\
\hline & & & $(0.010)$ & $(0.010)$ \\
\hline
\end{tabular}




\begin{tabular}{|l|c|c|c|c|}
\hline & $(1)$ & $(2)$ & $(3)$ & $(4)$ \\
\hline Single mother in 1990* young & & & -0.006 & -0.006 \\
\hline & & & $(0.024)$ & $(0.024)$ \\
\hline Mother unemployed during 1985-1990* young & & & -0.007 & -0.007 \\
\hline & & & $(0.010)$ & $(0.010)$ \\
\hline Constant & $0.069^{* *}$ & 0.040 & 0.055 & 0.051 \\
\hline & $(0.002)$ & $(0.036)$ & $(0.164)$ & $(0.164)$ \\
\hline Observations & 9797 & 9797 & 9797 & 9797 \\
\hline Number of groups & 4615 & 4615 & 4615 & 4615 \\
\hline R-squared & 0.02 & 0.02 & 0.03 & 0.03 \\
\hline
\end{tabular}

Robust standard errors in parentheses. * significant at 5\%; ** significant at $1 \%$. 
Table A 4 Sibling fixed effects model for parental welfare share of years 17-19 during ages 17-19 and child welfare use at the age of 24, siblings born in 1973-75 and 198183

\begin{tabular}{|c|c|c|c|c|}
\hline & (1) & (2) & (3) & (4) \\
\hline \multirow[t]{2}{*}{ Parental welfare share of years 17-19 } & -0.144 & -0.113 & -0.124 & -0.101 \\
\hline & $(0.077)$ & $(0.105)$ & $(0.076)$ & $(0.106)$ \\
\hline \multirow[t]{2}{*}{ Young } & $-0.035 * *$ & -0.017 & -0.015 & -0.016 \\
\hline & $(0.004)$ & $(0.012)$ & $(0.047)$ & $(0.047)$ \\
\hline \multirow[t]{2}{*}{ Sickness benefits mother share of years 17-19 } & & 0.001 & 0.000 & 0.001 \\
\hline & & $(0.012)$ & $(0.012)$ & $(0.012)$ \\
\hline \multirow[t]{2}{*}{ Sickness pension mother share of years $17-19$} & & 0.017 & 0.014 & 0.014 \\
\hline & & $(0.024)$ & $(0.024)$ & $(0.024)$ \\
\hline \multirow[t]{2}{*}{ Disability pension mother share of years 17-19 } & & 0.000 & 0.010 & 0.010 \\
\hline & & $(0.050)$ & $(0.054)$ & $(0.054)$ \\
\hline \multirow[t]{2}{*}{ Sickness benefits father share of years 17-19 } & & 0.007 & 0.007 & 0.007 \\
\hline & & $(0.013)$ & $(0.013)$ & $(0.013)$ \\
\hline \multirow[t]{2}{*}{ Sickness pension father share of years $17-19$} & & 0.030 & 0.028 & 0.028 \\
\hline & & $(0.025)$ & $(0.025)$ & $(0.025)$ \\
\hline \multirow[t]{2}{*}{ Disability pension father share of years 17-19 } & & 0.102 & 0.104 & 0.104 \\
\hline & & $(0.077)$ & $(0.077)$ & $(0.077)$ \\
\hline \multirow[t]{2}{*}{ Mother not employed share of years 17-19 } & & -0.028 & -0.030 & -0.030 \\
\hline & & $(0.017)$ & $(0.017)$ & $(0.017)$ \\
\hline \multirow[t]{2}{*}{ Father not employed share of years 17-19 } & & 0.006 & 0.008 & 0.008 \\
\hline & & $(0.018)$ & $(0.018)$ & $(0.018)$ \\
\hline \multirow[t]{2}{*}{ Mother finished high school at age 19} & & -0.034 & -0.044 & -0.043 \\
\hline & & $(0.032)$ & $(0.033)$ & $(0.033)$ \\
\hline \multirow[t]{2}{*}{ Mother finished college at age 19} & & -0.008 & -0.017 & -0.017 \\
\hline & & $(0.044)$ & $(0.044)$ & $(0.044)$ \\
\hline \multirow[t]{2}{*}{ Father finished high school at age 19} & & 0.008 & 0.005 & 0.006 \\
\hline & & $(0.022)$ & $(0.022)$ & $(0.022)$ \\
\hline \multirow[t]{2}{*}{ Father finished college at age 19} & & -0.020 & -0.024 & -0.023 \\
\hline & & $(0.026)$ & $(0.026)$ & $(0.027)$ \\
\hline \multirow{2}{*}{$\begin{array}{l}\text { Disposable family income total 17-19 } \\
(1000000 \text { 's of SEK) }\end{array}$} & & -0.000 & -0.000 & -0.000 \\
\hline & & $(0.002)$ & $(0.002)$ & $(0.002)$ \\
\hline \multirow[t]{2}{*}{ Single mother share of years $17-19$} & & 0.018 & 0.017 & 0.017 \\
\hline & & $(0.018)$ & $(0.018)$ & $(0.018)$ \\
\hline \multirow[t]{2}{*}{ Divorce during ages $17-19$} & & 0.009 & 0.009 & 0.009 \\
\hline & & $(0.022)$ & $(0.022)$ & $(0.022)$ \\
\hline
\end{tabular}




\begin{tabular}{|c|c|c|c|c|}
\hline & (1) & (2) & (3) & (4) \\
\hline \multirow[t]{2}{*}{$\mathrm{Nr}$ children $0-17$ in the household at age 19} & & 0.002 & 0.001 & 0.001 \\
\hline & & $(0.006)$ & $(0.006)$ & $(0.006)$ \\
\hline \multirow[t]{2}{*}{ Father born in Nordic country } & & -0.065 & -0.087 & -0.087 \\
\hline & & $(0.101)$ & $(0.103)$ & $(0.103)$ \\
\hline \multirow[t]{2}{*}{ Father born in Western country } & & -0.001 & -0.006 & -0.008 \\
\hline & & $(0.078)$ & $(0.077)$ & $(0.077)$ \\
\hline \multirow[t]{2}{*}{ Father born in East Europe } & & 0.081 & 0.060 & 0.060 \\
\hline & & $(0.173)$ & $(0.188)$ & $(0.188)$ \\
\hline \multirow[t]{2}{*}{ Father born outside Europe/Western country } & & 0.332 & 0.347 & 0.346 \\
\hline & & $(0.238)$ & $(0.233)$ & $(0.232)$ \\
\hline \multirow[t]{2}{*}{ Age of father at immigration } & & $-0.003^{*}$ & $-0.004 *$ & $-0.004 *$ \\
\hline & & $(0.001)$ & $(0.002)$ & $(0.002)$ \\
\hline \multirow[t]{2}{*}{ Average local unemployment } & & $0.008 * *$ & $0.008 * *$ & $0.008 * *$ \\
\hline & & $(0.003)$ & $(0.003)$ & $(0.003)$ \\
\hline \multirow[t]{2}{*}{ Local unemployment * welfare family } & & 0.007 & & 0.007 \\
\hline & & $(0.020)$ & & $(0.020)$ \\
\hline \multirow[t]{2}{*}{ Mother born in Nordic country $*$ young } & & & -0.025 & -0.025 \\
\hline & & & $(0.029)$ & $(0.029)$ \\
\hline \multirow[t]{2}{*}{ Mother born in Western country * young } & & & 0.093 & 0.093 \\
\hline & & & $(0.049)$ & $(0.049)$ \\
\hline \multirow[t]{2}{*}{ Mother born in East Europe * young } & & & 0.039 & 0.038 \\
\hline & & & $(0.031)$ & $(0.031)$ \\
\hline \multirow[t]{2}{*}{ Mother born outside Europe/Western country * young } & & & -0.142 & -0.142 \\
\hline & & & $(0.089)$ & $(0.089)$ \\
\hline \multirow[t]{2}{*}{ Father born in Nordic country $*$ young } & & & 0.035 & 0.035 \\
\hline & & & $(0.044)$ & $(0.044)$ \\
\hline \multirow[t]{2}{*}{ Father born in Western country * young } & & & 0.014 & 0.015 \\
\hline & & & $(0.048)$ & $(0.048)$ \\
\hline \multirow[t]{2}{*}{ Father born in East Europe * young } & & & 0.027 & 0.027 \\
\hline & & & $(0.070)$ & $(0.070)$ \\
\hline \multirow[t]{2}{*}{ Father born outside Europe/Western country * young } & & & -0.064 & -0.064 \\
\hline & & & $(0.069)$ & $(0.069)$ \\
\hline \multirow[t]{2}{*}{ Father unemployed during $1985-1990 *$ young } & & & 0.015 & 0.014 \\
\hline & & & $(0.018)$ & $(0.018)$ \\
\hline \multirow[t]{2}{*}{ Father only primary school in $1985-1990 *$ young } & & & -0.009 & -0.008 \\
\hline & & & $(0.010)$ & $(0.010)$ \\
\hline Mother only primary school in $1985-1990 *$ young & & & $0.022 *$ & $0.022 *$ \\
\hline
\end{tabular}




\begin{tabular}{|l|c|c|c|c|}
\hline & $(1)$ & $(2)$ & $(3)$ & $(4)$ \\
\hline & & & $(0.010)$ & $(0.010)$ \\
\hline Single mother in 1990* young & & & -0.004 & -0.004 \\
\hline & & & $(0.024)$ & $(0.024)$ \\
\hline Mother unemployed during 1985-1990* young & & & -0.006 & -0.006 \\
\hline & & & $(0.010)$ & $(0.010)$ \\
\hline Constant & $0.069^{* *}$ & 0.040 & 0.063 & 0.061 \\
\hline & $(0.002)$ & $(0.036)$ & $(0.164)$ & $(0.164)$ \\
\hline Observations & 9797 & 9797 & 9797 & 9797 \\
\hline Number of groups & 4615 & 4615 & 4615 & 4615 \\
\hline R-squared & 0.02 & 0.03 & 0.03 & 0.03 \\
\hline
\end{tabular}

Robust standard errors in parentheses. * significant at 5\%; ** significant at $1 \%$. 
Table A 5 Sibling fixed effects model for parental welfare/year during ages 17-19 and child welfare use at the age of 24, siblings born in 1973-75 and 1981-83

\begin{tabular}{|c|c|c|c|c|}
\hline & (1) & (2) & (3) & (4) \\
\hline \multirow[t]{2}{*}{ Parental welfare share of years 17-19 } & 0.001 & 0.003 & 0.002 & 0.003 \\
\hline & $(0.004)$ & $(0.004)$ & $(0.004)$ & $(0.004)$ \\
\hline \multirow[t]{2}{*}{ Young } & $-0.038 * *$ & -0.023 & -0.026 & -0.031 \\
\hline & $(0.004)$ & $(0.012)$ & $(0.047)$ & $(0.047)$ \\
\hline \multirow[t]{2}{*}{ Sickness benefits mother share of years 17-19 } & & -0.002 & -0.003 & -0.003 \\
\hline & & $(0.012)$ & $(0.012)$ & $(0.012)$ \\
\hline \multirow[t]{2}{*}{ Sickness pension mother share of years $17-19$} & & 0.008 & 0.006 & 0.006 \\
\hline & & $(0.024)$ & $(0.024)$ & $(0.024)$ \\
\hline \multirow[t]{2}{*}{ Disability pension mother share of years 17-19 } & & -0.036 & -0.037 & -0.036 \\
\hline & & $(0.054)$ & $(0.052)$ & $(0.053)$ \\
\hline \multirow[t]{2}{*}{ Sickness benefits father share of years 17-19 } & & 0.010 & 0.012 & 0.010 \\
\hline & & $(0.013)$ & $(0.013)$ & $(0.013)$ \\
\hline \multirow[t]{2}{*}{ Sickness pension father share of years $17-19$} & & 0.037 & 0.036 & 0.036 \\
\hline & & $(0.026)$ & $(0.027)$ & $(0.027)$ \\
\hline \multirow[t]{2}{*}{ Disability pension father share of years $17-19$} & & 0.084 & 0.085 & 0.086 \\
\hline & & $(0.081)$ & $(0.083)$ & $(0.082)$ \\
\hline \multirow[t]{2}{*}{ Mother not employed share of years 17-19 } & & -0.032 & $-0.038 *$ & $-0.035 *$ \\
\hline & & $(0.017)$ & $(0.018)$ & $(0.018)$ \\
\hline \multirow[t]{2}{*}{ Father not employed share of years 17-19 } & & 0.005 & 0.005 & 0.006 \\
\hline & & $(0.019)$ & $(0.019)$ & $(0.019)$ \\
\hline \multirow[t]{2}{*}{ Mother finished high school at age 19} & & -0.026 & -0.037 & -0.034 \\
\hline & & $(0.033)$ & $(0.034)$ & $(0.034)$ \\
\hline \multirow[t]{2}{*}{ Mother finished college at age 19} & & 0.001 & -0.011 & -0.006 \\
\hline & & $(0.045)$ & $(0.045)$ & $(0.045)$ \\
\hline \multirow[t]{2}{*}{ Father finished high school at age 19} & & 0.007 & 0.005 & 0.005 \\
\hline & & $(0.022)$ & $(0.022)$ & $(0.022)$ \\
\hline \multirow[t]{2}{*}{ Father finished college at age 19} & & -0.011 & -0.014 & -0.014 \\
\hline & & $(0.028)$ & $(0.029)$ & $(0.028)$ \\
\hline \multirow{2}{*}{$\begin{array}{l}\text { Disposable family income total 17-19 } \\
\text { (1 000 000's of SEK) }\end{array}$} & & -0.001 & -0.001 & -0.001 \\
\hline & & $(0.002)$ & $(0.002)$ & $(0.002)$ \\
\hline \multirow[t]{2}{*}{ Single mother share of years $17-19$} & & 0.024 & 0.018 & 0.021 \\
\hline & & $(0.019)$ & $(0.019)$ & $(0.019)$ \\
\hline \multirow[t]{2}{*}{ Divorce during ages $17-19$} & & 0.013 & 0.015 & 0.015 \\
\hline & & $(0.023)$ & $(0.022)$ & $(0.022)$ \\
\hline $\mathrm{Nr}$ children $0-17$ in the household at age 19 & & 0.000 & 0.001 & -0.000 \\
\hline
\end{tabular}




\begin{tabular}{|c|c|c|c|c|}
\hline & (1) & (2) & (3) & (4) \\
\hline & & $(0.006)$ & $(0.006)$ & $(0.006)$ \\
\hline \multirow[t]{2}{*}{ Father born in Nordic country } & & -0.039 & -0.061 & -0.057 \\
\hline & & $(0.103)$ & $(0.105)$ & $(0.105)$ \\
\hline \multirow[t]{2}{*}{ Father born in Western country } & & -0.020 & -0.024 & -0.031 \\
\hline & & $(0.047)$ & $(0.045)$ & $(0.046)$ \\
\hline \multirow[t]{2}{*}{ Father born in East Europe } & & 0.211 & 0.206 & 0.207 \\
\hline & & $(0.125)$ & $(0.134)$ & $(0.134)$ \\
\hline \multirow[t]{2}{*}{ Father born outside Europe/Western country } & & 0.263 & 0.274 & 0.275 \\
\hline & & $(0.228)$ & $(0.222)$ & $(0.222)$ \\
\hline \multirow[t]{2}{*}{ Age of father at immigration } & & $-0.003 *$ & -0.003 & -0.003 \\
\hline & & $(0.002)$ & $(0.002)$ & $(0.002)$ \\
\hline \multirow[t]{2}{*}{ Average local unemployment } & & $0.007 *$ & $0.009 * *$ & $0.007 *$ \\
\hline & & $(0.003)$ & $(0.003)$ & $(0.003)$ \\
\hline \multirow[t]{2}{*}{ Local unemployment $*$ welfare family } & & $0.034 *$ & & $0.032 *$ \\
\hline & & $(0.016)$ & & $(0.016)$ \\
\hline \multirow[t]{2}{*}{ Mother born in Nordic country * young } & & & -0.030 & -0.031 \\
\hline & & & $(0.029)$ & $(0.029)$ \\
\hline \multirow[t]{2}{*}{ Mother born in Western country * young } & & & 0.091 & 0.092 \\
\hline & & & $(0.050)$ & $(0.050)$ \\
\hline \multirow[t]{2}{*}{ Mother born in East Europe * young } & & & 0.048 & 0.051 \\
\hline & & & $(0.029)$ & $(0.030)$ \\
\hline \multirow[t]{2}{*}{ Mother born outside Europe/Western country * young } & & & -0.169 & -0.161 \\
\hline & & & $(0.097)$ & $(0.096)$ \\
\hline \multirow[t]{2}{*}{ Father born in Nordic country $*$ young } & & & 0.030 & 0.032 \\
\hline & & & $(0.042)$ & $(0.042)$ \\
\hline \multirow[t]{2}{*}{ Father born in Western country * young } & & & 0.022 & 0.022 \\
\hline & & & $(0.051)$ & $(0.051)$ \\
\hline \multirow[t]{2}{*}{ Father born in East Europe * young } & & & 0.001 & 0.000 \\
\hline & & & $(0.068)$ & $(0.068)$ \\
\hline \multirow[t]{2}{*}{ Father born outside Europe/Western country * young } & & & -0.071 & -0.070 \\
\hline & & & $(0.070)$ & $(0.070)$ \\
\hline \multirow[t]{2}{*}{ Father unemployed during $1985-1990 *$ young } & & & 0.016 & 0.015 \\
\hline & & & $(0.019)$ & $(0.019)$ \\
\hline \multirow[t]{2}{*}{ Father only primary school in $1985-1990 *$ young } & & & -0.010 & -0.009 \\
\hline & & & $(0.010)$ & $(0.010)$ \\
\hline \multirow[t]{2}{*}{ Mother only primary school in $1985-1990 *$ young } & & & $0.021^{*}$ & $0.022 *$ \\
\hline & & & $(0.011)$ & $(0.010)$ \\
\hline
\end{tabular}




\begin{tabular}{|l|c|c|c|c|}
\hline & $(1)$ & $(2)$ & $(3)$ & \multicolumn{1}{|c|}{$(4)$} \\
\hline Single mother in 1990* young & & & -0.026 & -0.021 \\
\hline & & & $(0.026)$ & $(0.026)$ \\
\hline Mother unemployed during 1985-1990* young & & & -0.009 & -0.007 \\
\hline & & & $(0.010)$ & $(0.010)$ \\
\hline Constant & 0.058 & 0.038 & 0.013 & 0.012 \\
\hline & $(0.146)$ & $(0.149)$ & $(0.215)$ & $(0.216)$ \\
\hline Observations & 9797 & 9797 & 9797 & 9797 \\
\hline Number of groups & 4615 & 4615 & 4615 & 4615 \\
\hline R-squared & 0.07 & 0.08 & 0.08 & 0.08 \\
\hline
\end{tabular}

Robust standard errors in parentheses. * significant at 5\%; ** significant at $1 \%$. 